\title{
Examining the Value of Money in Turkey over the Long Term (1469-2009)
}

\author{
Adam Abdullah ${ }^{1}$ \\ ${ }^{1}$ Faculty of Business Management and Accountancy, Universiti Sultan Zainal Abidin, Kuala Terengganu, \\ Malaysia \\ Correspondence: Adam Abdullah, Faculty of Business Management and Accountancy, University Sultan Zainal \\ Abidin, Gong Badak Campus, 21300 Kuala Terengganu, Terengganu, Malaysia. Tel: 60-9-668-8275. E-mail: \\ aabdullah@unisza.edu.my
}

Received: August 5, 2013 Accepted: September 9, 2013 Online Published: November 29, 2013

doi:10.5539/ass.v9n17p187 URL: http://dx.doi.org/10.5539/ass.v9n17p187

\begin{abstract}
This paper aims to examine the tremendous loss of value of money over the long term during the Ottoman Empire and the Republic of Turkey between 1469-2009. By 1844, 1.1 Ottoman lira exchanged for one English pound, but in 2005, 1.5 million Turkish lira exchanged for one U.S. dollar. By critically examining the value and purchasing power of money in Ottoman-Turkey, this paper compares empirical evidence and statistics through long term analysis of silver and commodity price indices, as to which medium of exchange provides for the best store of value. This paper discovers that monetary policy should not target stable prices, by managing the quantity or purchasing power of money, but instead adopt a monetary theory of value involving a stable currency, free of monetary management, permitting a stable purchasing power and thus stable prices.
\end{abstract}

Keywords: silver price, commodity prices, value of money, purchasing power of money

\section{Introduction}

This paper investigates the store of value function of money, by analyzing the value of money over the long term during the Ottoman Empire and the Republic of Turkey between 1469-2009. Whilst the purchasing power of money (PPM) is the inverse of the price level, and measures decline in the real value of money due to inflation (Rothbard, 1983, p.30), it would not tell us what is the cause of inflation. There is a difference between the value of money (VM) or the rate of exchange between a currency for a fixed amount of precious metal being the price of gold (PG) or silver (PS), from the PPM in terms of what money can buy at a particular point in time, reflecting the ratio of exchange between commodities and money (Ricardo, 2004, p. 90). By analyzing indices for the VM, the PPM and wholesale commodity prices (WPI) in Ottoman-Turkey, we find that a monetary theory of value, rather the a quantity theory or mercantilist Keynesian purchasing power theory, provides for a satisfactory interpretation of their causal significance and indeed their inter-relationships. Whilst, changes in the general level of commodity prices, reveals the relative value of money (Warren, 1935, p. 10), price movements are statistically defined by a price index and its reciprocal is the PPM (Fisher, 1911, p. 184). Since the Ottomans primarily used silver as their medium of exchange, the purchasing power of silver (PPS) involves how many commodities can be bought with the proceeds of a given amount of silver. This involves the construction of an index comprising a unified series of the PS, divided by an index of a unified series of wholesale commodity prices (WPI), and requires discussion on the construction of indices for the PS and WPI, including the compilation of relevant price data, the type of mean to be adopted, the types of commodities and the treatment of missing values. Beveridge stipulated that the analysis of long terms prices involves "a study not of isolated facts but of relations; comparison is its essence" (Beveridge, 1965, p. xxvi), and in determining how the VM effects the PPM, we can convert nominal prices into bullion equivalents "for the special purposes of relating prices to...currency policy" (Beveridge, 1965, p. xlvii). Whatever the decrease in the bullion content of specie or devaluation of paper, Ottoman silver coinage followed by Turkish paper money, have remained over the long term as a medium of exchange, a unit of account, a standard of deferred payment, but any changes in the store of value function of money can be measured by changes in the VM, which affects the PPM and this in turn affects WPI.

Jastram $(1977,1981)$ studied gold and silver over the long term in England and the U.S. from 1560-1979. He 
argued that both gold and silver had become manipulated and de-monetized commodities, and concluded that whilst a monetary system should be managed, gold is not money and there would be no return to a gold standard (Jastram, 1977, pp. 73, 181-5). He acknowledged that the PPG was maintained over the long term, concluding that gold was not a good hedge against inflation but rather deflation (Jastram, 1977, p. 132). He observed that silver had experienced considerable manipulation over time (Jastram, 1981, p. 158). However, analysis of data in England between 1259-2009 firmly rejected this view (Abdullah, March 2013), and together with this article on Ottoman data, it will become evident that the same principle applies across whatever geography, background or chronology: when a monetary theory of value prevails, by maintaining a high value of circulating specie, the affect on the PPM, is such that the general price level remains low and stable over the long term. Ottoman data compiled for TurkStat by Professor Şevket Pamuk (Note 1) has also been included in our analysis. Ottoman data presented by Pamuk $(2000,2002,2004)$ between 1496-1914 and also European data presented by Allen (1974) between 1500-1914, utilized consumer prices attributable to urban consumers in major financial centres, in conjunction with numismatic data on the actual weight of the silver content of coins. In essence, we have the same original numismatic and wholesale price data obtained from TurkStat, and construct a simple geometric wholesale price index as a deflator for the purchasing power of the akche, whilst Pamuk's index is a consumer price index weighted according to relative expenditure, constructed in a similar fashion to the Brown Hopkins Index (Note 2) and used as a deflator for nominal wages. No mint price or market price of bullion is supplied since Muslims were not operating a bimetallic or even a silver standard, but were transacting by specie and not by tale. Data is given on official/market exchange rates between Ottoman and European coins and various gold:silver ratios. Pamuk was mainly addressing the data from the perspective of a monetary and price historian, and although his quantity theory analysis implied that money stock and velocity did not change much over the Ottoman period, he hoped that "future research will be able to provide more reliable and more detailed answers to these and other questions" (Pamuk, 2000, pp. 241-242), which is precisely the aim of this paper and its monetary theory of value rather than a quantity theory interpretation. Pamuk's index nonetheless provides for an excellent comparative analysis and he also concluded that nominal prices in Istanbul increased due to debasement. Furthermore, evidence suggests that over the medium-long term, price trends in Istanbul and other parts of the Mediterranean, showed that trade across the Mediterranean, tended to bring prices expressed in grams of silver together (Pamuk, 2000, p. 240). In summary, our data contrasts with that of Pamuk for we analyze data from 1496-2009 (rather than to 1914) involving Ottoman and Turkish data. In the case of Ottoman data, as summarized in TurkStat, we adopt a simple geometric mean (as opposed to a weighted arithmetic mean) in the construction of a wholesale price index involving 16 food and non-food items (as opposed to 15) up to 1860, and then 15 food and non-food items up to 1914. We also derive our own missing values from observed values as per the methodology.

This paper is organized into four sections. In the first section we have provided an introduction concerning the analysis of the value and purchasing power of money in Ottoman-Turkey over the long term. The second section details the methodology in constructing indices for the value of silver and wholesale commodity prices from 1469-2009, involving the construction of an WPI from 1469-1914, including the compilation of price series, the treatment of missing values, the type of mean, and linking up with other indices from 1914-2009. The third section presents an analysis and discussion of our Ottoman and Turkish data involving a monetary theory of value, whilst the fourth section provides some concluding remarks.

\section{Methodology}

This section deals with the compilation of indices on the value of silver and commodity prices, and addresses the construction of price series, the type of mean, missing values and overall index compilation including statistical analysis. For a monetary unit of account that is defined by its weight in silver, such as the Ottoman akche, this paper seeks to examine available impact on nominal prices by constructing a wholesale price index (WPI) reflecting prices for basic commodity prices in Istanbul, together with data on the silver content of the akche from 1469-1914. Fortunately, we have considerable data made available by the Turkish Statistical Institute (TurkStats, 2000). The akche represented both the official standard of value under the Ottoman Empire and an actual silver coin in circulation. Nonetheless, such was the reduced purchasing power of the akche over time, that larger silver coins were minted with the zolota in 1690 and the kurus in 1703, and the silver content of the akche was subsequently extrapolated from the prevailing exchange rate of 120 akche per kurus. Table 1 provides us with the sources for the compilation of data on Ottoman and Turkish currency. 
Table 1. Compilations of Ottoman \& Turkish currency, 1469-2009

\begin{tabular}{ccccc}
\hline Source & Period & Observations & Denomination & Decimals \\
\hline TurkStats (Note 3) & $1469-1914$ & annual & Sultani (Note 4), lira (Note 5), kurus (Note & 2 \\
Central Bank of Turkey & $1946-2009$ & annual & 6), akche (Note 7) & 2 \\
(Note 8) & & & lira & 2 \\
\hline
\end{tabular}

The gold sultani coin (similar to the Venetian ducat) was first minted in 1477 , but no formal bimetallic ratio existed until 1844 with the introduction of the gold lira, which exchanged at 100 kurus. The weight and fineness of the sultani was largely held steady, but both the akche and subsequently the kurus were debased. This paper will primarily concentrate on the akche, but given available exchange rate data (Note 9), we can also construct a long-term view of the value of silver, involving the akche and kurus silver coinage up to WWI, followed by the New York market price of silver in USD converted into lira at the prevailing lira/USD rate of exchange.

We can deflate the Ottoman currency in terms of its precious metal content in order to assess the VM, and in terms of prices in order to assess the PPM. In terms of prices, we can construct a wholesale price index (WPI), calculated on the basis of a geometric mean, for standard food and non-food items utilizing the TurkStat data collected from more than 6,000 account books and price lists located in Ottoman archives in Istanbul. Prices of 5 non-food items mainly from the Topkapi palace (saray) account books were included with 11 food-prices paid by three institutions: (i) pious foundations (waqf) and their soup kitchens ( ${ }^{c}$ imaret), (ii) the Topkapi palace kitchen and (iii) official price ceilings (narh) for basic items of consumption in the capital city of Istanbul. From 1863 data from the saray waqf and narh sources is limited, so the over-all WPI links the earlier data with data of 15 wholesale commodity prices of the Commodity Exchange of Istanbul from 1863-1914 published by the Istanbul Chamber of Commerce (ICC) and also included in the data published by TurkStat. By constructing a geometric index of the ICC prices, it can be linked into the over-all geometric WPI, and thereafter we can link our WPI into existing WPIs supplied by the ICC and TurkStat from 1914-2009. We can compare our wholesale price index involving a simple geometric mean with Pamuk's consumer price index involving an arithmetic mean weighted according to relative expenditure.

The type of index and mathematical mean requires analysis in evaluating a stochastic measurement of inflation and the PPM and our approach to index number construction echoes Abdullah (March, 2013). Fisher concluded that, "if the simple weighting does not happen to be too erratic, the geometric is the best formula" (Fisher, 1922, p. 212) and used it in his quantity theory equation of exchange, $M V=P T$, where the volume of trade $(\mathrm{T})$ reflected in the quantity of goods $(\mathrm{Q})$ purchased by prices $(\mathrm{P})$. Hence, index numbers of $\mathrm{P}, \mathrm{T}$ (and $\mathrm{Q}$ ) involve $P_{1} T_{1}=$ $\sum P_{1} Q_{1}$ and Fisher's "ideal" formula (Fisher, 1911, p. 418; 1922, pp. 197, 241-2) reflects the geometric cross (mean) of Walsh's (1901, p. 429) involving Laspèyre with the base reference year quantities as weights, and Paasche with the current year quantities as weights, or $\sqrt{(L P)}$ as reflected in (1) for prices and (2) for quantities.

$$
\begin{aligned}
\text { for prices (price index) } & \sqrt{\frac{\sum P_{1} Q_{0}}{\sum P_{0} Q_{0}} \cdot \frac{\sum P_{1} Q_{1}}{\sum P_{0} Q_{1}}} \\
\text { for quantities (quantity index) } & \sqrt{\frac{\sum Q_{1} P_{0}}{\sum Q_{0} P_{0}} \cdot \frac{\sum Q_{1} P_{1}}{\sum Q_{0} P_{1}}}
\end{aligned}
$$

Our analysis involves historical prices without any consumption data for weighting. The unweighted arithmetic ratio-of-aggregates $\left(\sum P_{1} / \sum P_{0}\right)$ has a heavy inherent bias (Jastram, 1977, p. 68), the geometric mean is the best measure for the average ratio of change in prices (Mitchell, 1938, p. 76), and an unbiased simple index will result only in minor differences when compared to a weighted index (Fisher, 1922, p. 445). Rather than adopt the arithmetic mean we have chosen a simple geometric mean of a set of price-ratios (3),

$$
\eta \sqrt{\frac{P_{1}}{P_{0}} \cdot \frac{P_{1}^{\prime}}{P_{0}^{\prime}} \ldots}
$$

This was originally known as the Jevons Index (Jevons, 1883, p. 332) being identical to the unweighted geometric mean prices (4) (ILO-PPI, 2004, p. 217). 


$$
P_{J}=\Pi\left(\frac{P_{1}}{P_{0}}\right)^{1 / n}=\frac{\Pi\left(P_{1}\right)^{1 / n}}{\Pi\left(P_{0}\right)^{1 / n}}
$$

Other than the distinction between the construction of the Jevon's index on the basis of mean prices or mean price relatives, different methodologies exist in terms of current-to-reference year price ratios for a direct index on reference year, and year-to-year price relatives for a chained year-to-year index: both will produce the same geometric index number as aggregate prices, but not with a year-to-year index, and all results differ with the (Carli or Dutot) arithmetic indices. Various calculations of selected arithmetic and geometric price indices are detailed in table 2 (involving hypothetical observations).

Table 2. Calculation of price indices

\begin{tabular}{|c|c|c|c|c|c|c|c|c|}
\hline Year & Wheat & $\begin{array}{l}\text { prices } \\
\text { Corn }\end{array}$ & Rice & Beans & $\begin{array}{c}\text { arithmetic } \\
\text { mean prices }\end{array}$ & $\begin{array}{l}\text { Dutot Index, } \\
\text { ratio of } \\
\text { arithmetic mean } \\
\text { prices }\end{array}$ & $\begin{array}{c}\text { geometric } \\
\text { mean prices }\end{array}$ & $\begin{array}{l}\text { Jevons Index, } \\
\text { ratio of } \\
\text { geometric mean } \\
\text { prices }\end{array}$ \\
\hline 1500 & 6.0 & 7.0 & 2.0 & 5.0 & 5.0 & 100.00 & 4.53 & 100.00 \\
\hline 1501 & 6.0 & 7.0 & 3.0 & 5.0 & 5.3 & 105.00 & 5.01 & 110.67 \\
\hline 1502 & 7.0 & 6.0 & 4.0 & 5.0 & 5.5 & 110.00 & 5.38 & 118.92 \\
\hline 1503 & 6.0 & 7.0 & 5.0 & 4.0 & 5.5 & 110.00 & 5.38 & 118.92 \\
\hline 1504 & 6.0 & 7.0 & 2.0 & 5.0 & 5.0 & 100.00 & 4.53 & 100.00 \\
\hline 1505 & 6.0 & 7.2 & 3.0 & 5.0 & 5.3 & 106.00 & 5.05 & 111.45 \\
\hline 1506 & 6.6 & 7.7 & 2.2 & 5.5 & 5.5 & 110.00 & 4.98 & 110.00 \\
\hline \multicolumn{6}{|c|}{ current-to-reference year price ratios } & $\begin{array}{l}\text { Carli arithmetic } \\
\text { direct index on }\end{array}$ & & $\begin{array}{c}\text { Jevons geometric } \\
\text { direct index on }\end{array}$ \\
\hline Year & Wheat & Corn & Rice & Beans & & base year & & base year \\
\hline 1500 & 1.00 & 1.00 & 1.00 & 1.00 & & 100.00 & & 100.00 \\
\hline 1501 & 1.00 & 1.00 & 1.50 & 1.00 & & 112.50 & & 110.67 \\
\hline 1502 & 1.17 & 0.86 & 2.00 & 1.00 & & 125.60 & & 118.92 \\
\hline 1503 & 1.00 & 1.00 & 2.50 & 0.80 & & 132.50 & & 118.92 \\
\hline 1504 & 1.00 & 1.00 & 1.00 & 1.00 & & 100.00 & & 100.00 \\
\hline 1505 & 1.00 & 1.03 & 1.50 & 1.00 & & 113.21 & & 111.45 \\
\hline 1506 & 1.10 & 1.10 & 1.10 & 1.10 & & 110.00 & & 110.00 \\
\hline \multicolumn{5}{|c|}{ year-to-year price ratios } & $\begin{array}{c}\text { Carli } \\
\text { arithmetic } \\
\text { year to year } \\
\text { index of } \\
\text { price ratios }\end{array}$ & $\begin{array}{l}\text { Carli arithmetic } \\
\text { chained year to } \\
\text { year index of } \\
\text { price ratios }\end{array}$ & $\begin{array}{c}\text { Jevons } \\
\text { geometric } \\
\text { year to year } \\
\text { index of } \\
\text { price ratios }\end{array}$ & $\begin{array}{c}\text { Jevons geometric } \\
\text { chained year to } \\
\text { year index of } \\
\text { price ratios }\end{array}$ \\
\hline 1500 & 1.00 & 1.00 & 1.00 & 1.00 & 100.00 & 100.00 & 100.00 & 100.00 \\
\hline 1501 & 1.00 & 1.00 & 1.50 & 1.00 & 112.50 & 112.50 & 110.67 & 110.67 \\
\hline 1502 & 1.17 & 0.86 & 1.33 & 1.00 & 108.93 & 122.54 & 107.46 & 118.92 \\
\hline 1503 & 0.86 & 1.17 & 1.25 & 0.80 & 101.85 & 124.81 & 100.00 & 118.92 \\
\hline 1504 & 1.00 & 1.00 & 0.40 & 1.25 & 91.25 & 113.89 & 84.09 & 100.00 \\
\hline 1505 & 1.00 & 1.03 & 1.50 & 1.00 & 113.21 & 128.93 & 111.45 & 111.45 \\
\hline 1506 & 1.10 & 1.07 & 0.73 & 1.10 & 100.07 & 129.02 & 98.70 & 110.00 \\
\hline
\end{tabular}

Source: Adapted from ILO-PPI:216 
Mitchell (1938) noted three attributes for the geometric mean:

"First, unlike the arithmetic mean, [the geometric mean] is not in danger of distortion from the asymmetrical distribution of price fluctuations...If, for example, one commodity rose tenfold in price and another commodity fell to one-tenth of the old price, the arithmetic mean would show and average rise of 505 per cent $(1,000+10) / 2$, while the geometric mean would show no change in the average, since $\sqrt{(1,000 \times 10)}=100$ The second merit claimed for the geometric mean is that they can be shifted from one base period to the other without producing results that seem to be inconsistent...A third advantage of the geometric means is that they are likely to be nearer the modes of distributions, which they represent than are arithmetic means" (pp. 69-71).

Table 3 summarizes the compilation of our sources for the construction of our combined Ottoman / Turkish wholesale price index.

Table 3. Compilations of Istanbul \& Turkish commodity prices, 1469-2009

\begin{tabular}{cccc}
\hline Source & Period & Time Base or Currency & Price Measure \\
\hline TurkStat (Note 10) & $1469-1914$ & $a k c h e$, grams of silver & wholesale \\
ICC (Note 11) & $1914-1941$ & 1900 & wholesale \\
TurkStat / ICC (Note 12) & $1941-2009$ & 1938,1968 & wholesale \\
\hline
\end{tabular}

For any missing values we mainly interpolated from existing values within individual price series. Whilst this would dampen annual movements, the overall price trend is retained for our long term analysis, and in this instance we take Allen's methodology for estimating missing prices in his European price indices as our precedent: "[missing values] were filled by interpolation. As a result, year-to-year fluctuations in the price level are damped, but the general trends and relative levels...are preserved" (Allen 2001, p. 420). Alternatively, estimated values were also indexed from observed values in related price series, to capture the annual price movements.

The paper will also examine the relationship between debasements and prices, by analyzing the WPI in real terms, expressed in terms of the weight of silver in grams, or silver content of the akche (SC), where WPI (in silver) $=$ WPI (in akches) x SC. However, perhaps more significantly, since the purchasing power of the akche (PPA) is an inverse of nominal prices expressed in akche, when adjusted for inflation, comparisons can then be made with the purchasing power of other units of account in real terms. This paper will also examine the affect of paper money and external debt during the $19^{\text {th }}$ century, following the extensive debasement and reduction in the PPA as the Ottoman monetary unit of account, which may reveal a great deal concerning the demise of the Ottoman Empire under the weight of external borrowings. Furthermore, this paper will also analyze the reduction in purchasing power of the lira (PPL), which started off as a gold coin in 1844 under the gold standard, and demonstrate how post WWII, the Turkish lira as paper money, eventually became the world's most devalued currency.

In evaluating the performance of the various Ottoman-Turkish monetary systems, we can provide an analysis of both the long-term stability and short-term volatility of prices (Mueller, 2010, pp. 329-331, 441). However, this serves to not only rank the medium of exchange, but also the performance of the prevailing monetary authorities. Nonetheless, we have adopted two measures of comparison for the relevant periods: (i) long term price stability measured by the average absolute annual change in WPI, and (ii) short term volatility, measured by the standard deviation of annual WPI changes, derived from the population standard deviation (5),

$$
\sigma=\sqrt{\frac{\sum(x-\bar{x})^{2}}{n}}
$$

We can rank each monetary system by weighing stability and volatility equally. Our bullion and price series involves the compilation of a full population of data and additional statistical analysis involves determining the correlation coefficient for a full population to measure the strength of dependence between the PS and the WPI in order to assess the decline in the VM upon WPI. However, by determining a full population of real prices in terms of silver (WPIs), we may precisely explain causality between a decrease in the store of value and higher nominal WPI (in terms of akche or lira). 


\section{Analysis of Ottoman Empire / Turkey Data}

In this section we present our finding on the value and purchasing power of money and related monetary policy under the Ottomans and in the Republic of Turkey. In order to satisfy the objectives and present findings from 1469 to 2009, we have to overcome a challenge, in that the unit of account under the Ottomans was a silver coin called the akche, and the unit of account of Turkey is the paper lira, and we will therefore detail how we link the two monetary systems. Moreover, the Ottomans exchanged by specie and not by tale, only experiencing bimetallism from 1844 with the introduction of the gold lira, and a gold standard from 1873, although silver coins were still in circulation until WWI. We will also have to detail how we obtain the equivalent of an a priori published price of silver in order to compare with the international price post WWI, so that we are able to express the VM and indeed evaluate the PPM and the PPS over the long term. At this point, we intend to concentrate on silver, since in the Ottoman monetary system, the silver akche was the basic unit of account and the primary means of payment in local transactions (Pamuk, 2004, p. 70), thereby facilitating a link with the price of silver under the Republic of Turkey. This paper recognizes the correlation between monetary stability, price trends and economic conditions over the long term, but in the first instance, we need to clarify the relevant historical monetary standards, before presenting our findings and then analyzing the affect of debasement and related monetary policy issues.

The silver content of the akche changed with debasements conducted by the government, whilst the Ottoman gold sultani coin remained similar to the Venetian ducat, and its market rate of exchange expressed in akches would fluctuate according to the silver content of the akche. There was no fixed bimetallic gold:silver ratio around which the face value of the monetary standard of both types of coins would be determined. This is distinct from the English and American monetary systems that would define the currency unit, the GBP and the USD, in terms of a fixed amount of gold or silver, known as the mint ratio or the official legal ratio, so that the authorities fixed the face value of both gold and silver coins. Technically, the Ottoman monetary system involved monometallism, whereby one commodity standard existed, being the silver akche as the basic unit of account, in terms of which the value of other commodities are measured even if the circulation of money may include several metallic or indeed paper units, including the gold sultani and the copper mangir. The flexibility of a monetary system that allowed coins to pass by specie rather than by tale, mean that as long as the market rate of exchange reflected the intrinsic value of coinage, then there would not likely be coins that were either over or indeed under valued and thus did not disappear from the markets as a medium of exchange, as we would expect under bimetallism and Gresham's Law. The Ottomans adhered to this until the bimetallism was enacted in 1844 with the introduction of the gold lira coin.

During the Umayyads and Abbasids the dinar was a recognized stable standard of payment, and was often used as a medium of exchange throughout the Mediterranean. By the time of the Mamluks, the 4.25g dinar had been devalued by $20 \%$ in $829 \mathrm{H} / 1425$ to the $3.4 \mathrm{~g}$ ashrafi (named after Barsbay, al-Malik al-Ashraf), which was slightly lighter than the Venetian ducat and became the standard Mamluk gold coin. The first Ottoman gold coin, the sultani, was minted in $882 \mathrm{H} / 1477$ and was exchanged at par to the ducat, reflecting the latter's popularity as a trade coin. Ottoman coins were based on the Tabriz mithqal: from 100 Tabriz mithqals 129 sultanis were initially minted weighing 3.572g of 0.997 fine (Pamuk, 2000, p.63). The Tabriz mithqal $=24$ karats $=1.5$ dirhams. Each karat $=4$ habbah of wheat. Since the grain of wheat weighs approximately $0.048 \mathrm{~g}$, the karat $=$ $0.192 \mathrm{~g}$, the Tabriz mithqal $=96$ habbahs $\times 0.048=4.608 \mathrm{~g}$, and the dirham $=4.608 / 1.5=3.072 \mathrm{~g}$ (Kabaklarh, 2007, p. 33). In 1477, from 100 mithqals $=100$ x $4.608 / 129=3.572 \mathrm{~g}$ Sultanis were minted. From 100 mithqals, the weight was reduced in 1526 to 130 sultanis $(3.545 \mathrm{~g}$ ), and in 1564 to 131 sultanis $(3.518 \mathrm{~g}$ ), with the 0.997 fineness unchanged (Pamuk, 2000, p. 63). At that time, the Venetian ducat (zecchino or sequin) $=3.4909 \mathrm{~g}$ of 0.986 fineness or $0.1107 /$ troy oz actual gold weight (3.4909 x $0.986 / 31.103)$, comprising of 54 troy grains, was first minted in 1284, adopting similar standards to the florin of Florence which was struck in 1252.

The Tabriz mithqal was distinct from the dinar mithqal, which weighed 72 grains of barley (Al-Maqrizi, 1994, p. 57), since the former reflected a Persian coin standard of the Il Khanate and was based on the wheat grain rather than the barley grain (Kabaklarh, 2007, p. 33). The mithqal was an ancient weight: in Persia it was historically derived from the weight of 24 chick-peas (nakhod), each weighing 4 gandums or wheat grains (Frey, 1917, p. 151), whereas the Romans originally used karats (carob seeds), a term used by the Arabs (qirat). The Arabic word nuqud (gold and silver coins) is derived from the Persian nakhod (a weight for gold and silver). Mahmud Ghazan Khan (694-704H/1295-1304), had no doubt learnt from the short reign and demise of his uncle Gaykhatu Khan, following the latter's failed experiment at issuing paper money in 1294, and having moved the administrative capital of the Il Khanate to Tabriz in 1295, ordered in 696H/1296-7 that all coins of the regional governments, under the sovereignty of the Il-Khan, including the Ottomans, would be fixed according to the 
Tabriz mithqal, as part of his monetary reformation. Thus, the Ottomans paid taxes to the Il Khan in dirhams weighing $3.072 \mathrm{~g}$, and when they subsequently minted their first silver coin in 1326, the akche (Note 13) weighing $1.152 \mathrm{~g}$, it was supposed to be struck from a pure (halis ayar) silver (Pamuk, 2000:46), whilst in practice the Ottomans may have typically achieved a fineness of 23-231/2 carats (Kabaklarh, 2007, p. 36).

During the first and second reigns of Mehmed II (1444-1481) the weight and purity of the akche was reduced 6 times, once every 5-10 years, and on each occasion the government would call in the old coins and mint new coins with a seigniorage of as much as $15-20 \%$ (Pamuk, 2000, pp. 48,50). Thus in 1444 the akche weighed $1.06 \mathrm{~g}$ but declined to $0.75 \mathrm{~g}$ by 1481 and the purity shrank from $23^{1 / 2}$ to 23 carats (Kabaklarh, 2007, p. 36). In fact, between 1326 and 1582 the akche was reduced from 1.15g to 0.68g (Pamuk, 2000, pp. 46, 63) (Note 14), although the purity could have been about 23 carats throughout (Kabaklarh, 2007, p. 36). Therefore, the government typically increased the number of coins in circulation from the same amount of silver and accordingly the akche became a visually smaller coin (Pamuk, 2000, p. 48). Generally, fiscal conditions supported the stability of the akche, and with the exception of Mehmed II, Ottoman governments refrained from debasements until the end of the $16^{\text {th }}$ century. On the other hand, they maintained the value of the gold sultani, in order to adhere to international standards as reflected in the ducat, for long distance payments, and the benefit from gold debasement would have been minimal since government obligations were expressed in terms of the akche (Pamuk, 2004, p. 72).

With notable debasement resuming from 1585-1586, and with the weight and silver content reducing to $0.3 \mathrm{~g}$ in 1640, the Ottomans began minting new silver paras based on the monetary unit in circulation in Egypt and carried three times as much silver as the akche. However, faced with fiscal difficulties the government resorted to minting copper coins (mangir) in 1690-1691, which attracted many counterfeit versions so that they were discontinued. The decline of the akche reflected a loss of control over the currency and implied loss of control over the economy, and as such new larger silver coins were minted modeled after European coins that were already circulating in Ottoman markets (Pamuk, 2004, pp. 130,142,158-159). In 1690 the silver zolota of 19.2g and $60 \%$ silver was minted, and in 1703 followed by the silver kurus (piastre) of $20 \mathrm{~g}$ with close to $60 \%$ silver: 1 kurus $=40$ para $=120$ akche, and 1 zolota $=3 / 4$ of a kurus or 90 akches: the kurus and the zolota were used in larger transactions and the para and the akche for smaller ones.

Following the Great Debasement of 1808-1834 during the rule of Mahmud II (1808-1839), whom embarked on reformist Western-style centralization and encountered fiscal problems following centralization and war, the Empire contracted losing Algeria (1830) and Tunisia (1831) to France, and Egypt (1882) became a de facto British colony (Pamuk, 2004, pp. 188,206). Indeed, the establishment of private British owned and controlled central banks, the Ottoman Bank (1856), the Imperial Bank of Persia (1889), and the National Bank of Egypt (1898), saw the British franchise their Bank of England fractional reserve banking model (and the first public bank in Turkey upon the collapse of the Caliphate in 1924).

Accordingly, monetary reform soon followed that saw the Ottoman government following international standards by introducing bimetallism and paper money. In 1844 the new gold lira was introduced as the main monetary unit, weighing $7.216 \mathrm{~g}$ of $22 / 24$ fineness containing $6.615 \mathrm{~g}$ of pure gold and equaled $100 \mathrm{kurus}$, each weighing $1.2 \mathrm{~g}$ containing $1 \mathrm{~g}$ of pure silver or $83.33 \%$ fine, thus a bimetallic standard of $6.615 \mathrm{~g}$ of gold to $100 \mathrm{~g}$ of silver, implied a gold:silver ratio of 15.09 (Pamuk, 2000, pp. 191,209). Following the adoption of paper money in the 1920s, 1 gold lira $=9$ paper lira; in 1946 a peg of 2.8 lira/dollar was adopted until 1960 when the lira was devalued to 9 lira/dollar; post Bretton Woods and in 2001 the lira was worth 1.65 million lira/dollar, and revalued in 2005 by dividing the old lira by one million, thus eliminating the zeros, but not the cumulative transfer of wealth to the bankers through inflation. Following the transition period for the revaluation between 2005-2008, the new lira in 2009 is worth about 1.5 lira/dollar.

Earlier we discussed the construction of indices for the PS and WPI. This paper will also discuss our findings involving the PPS; the purchasing power of the akche (PPA) being the Ottoman akche and Turkish lira adjusted by WPI, in conjunction with the purchasing power of the lira, in order to assess the overall purchasing power of Ottoman-Turkish money (PPM); and the SC of the akche as the intrinsic value of the Ottoman akche in terms of silver (OAs), the inverse of which would the nominal PS. This paper will also discuss nominal WPI expressed in terms of silver (WPIs), in order to accurately establish the nature of debasement of the akche and devaluation of the lira as a units of account, whether as specie or as fiat money. We may then interpret our findings through a monetary theory of value, and relate the value in exchange with real prices.

We begin by presenting our deflator for the PPM over the long term, and the exponential growth associated with wholesale prices can be observed in figure 1 . Since $\mathrm{P}=1 / \mathrm{PPM}$, we can then equally observe the exponential 
decay in the PPM in figure 2, in this case being a function of the silver akche (PPA) followed by the paper lira (PPL). The extent of price inflation and the exponential decay in the PPM is quite extraordinary, which involves an astonishing transfer of wealth as a result.

WHOLESALE PRICE INDEX, ISTANBUL/TURKEY, 1469-2009 (1469=1)

(logarithmic scale)

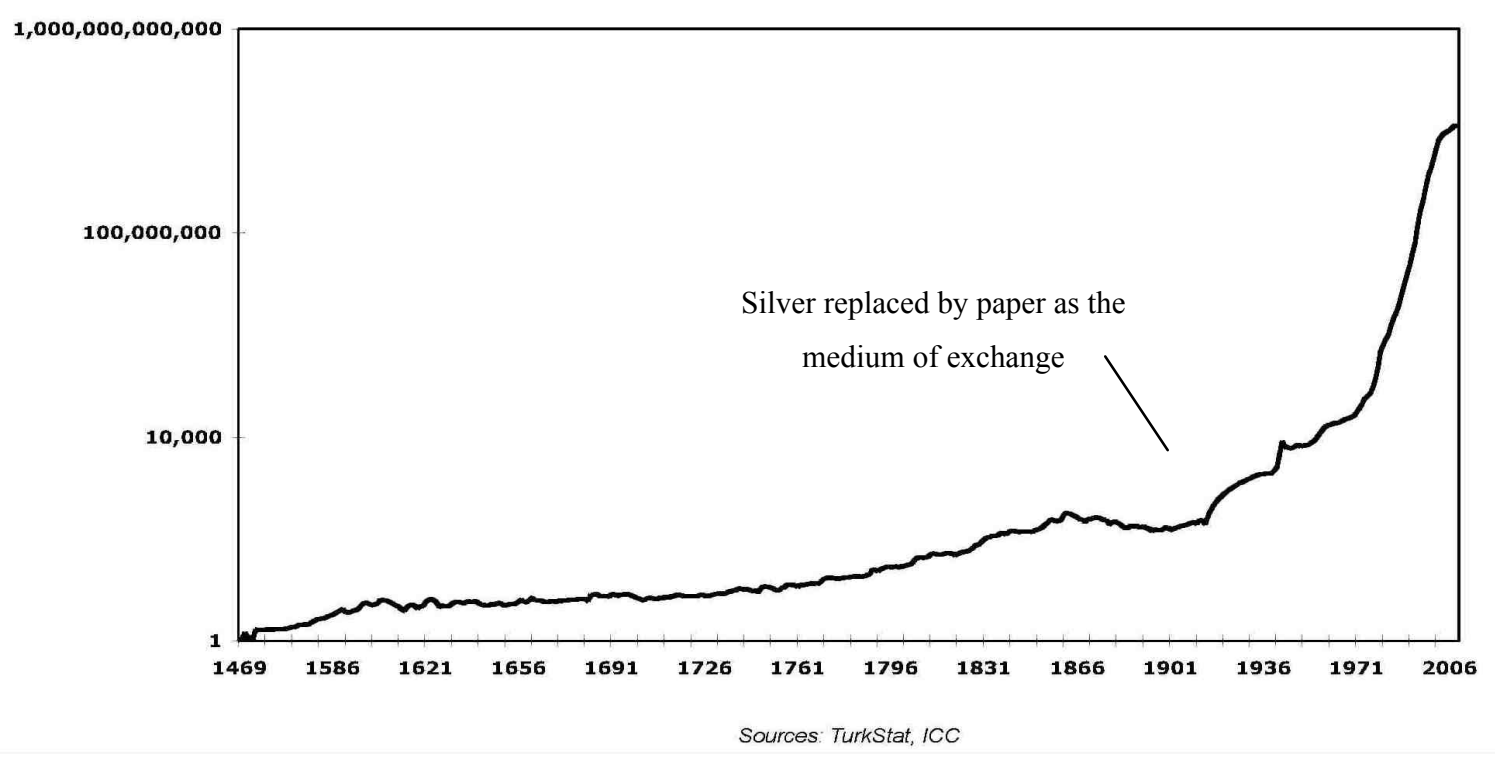

Figure 1. Wholesale price index, Istanbul/Turkey, 1469-2009

The exponential decay in the PPM was caused by the decline in the VM, as reflected in the rate of exchange with a precious metal, caused by an excessive supply of money in relation to demand, the result of which was an increase in the price level, so that the increase in WPI was the effect and not the cause.

PURCHASING POWER OF MONEY, ISTANBUL/TURKEY, 1469-2009 (1469=1)

(logarithmic scale)

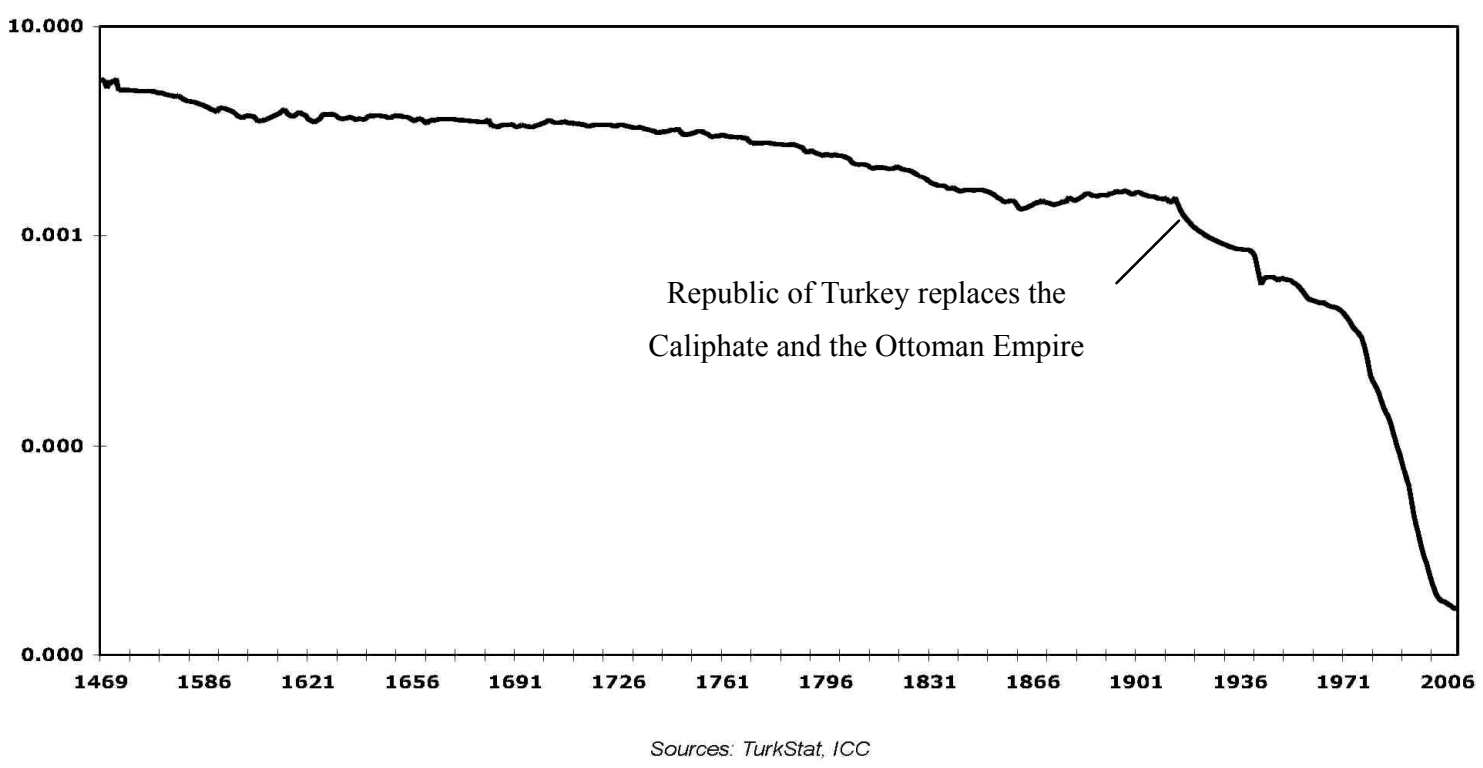

Figure 2. Purchasing power of money, Istanbul/Turkey, 1469-2009 
The international price of silver (and gold) was fixed in London and published in U.S. dollars from 1919, and coupled with the rates of exchange between the gold lira, the paper lira and the U.S. dollar during WWI (Pamuk, 2000, pp. 209,223-223; Pamuk, 2004, 2, p. 972), and between the paper lira and the dollar after 1919 (TurkStat, CBRT), we can construct a series for the price of silver (PS) since 1914 in lira per troy oz (figure 3).

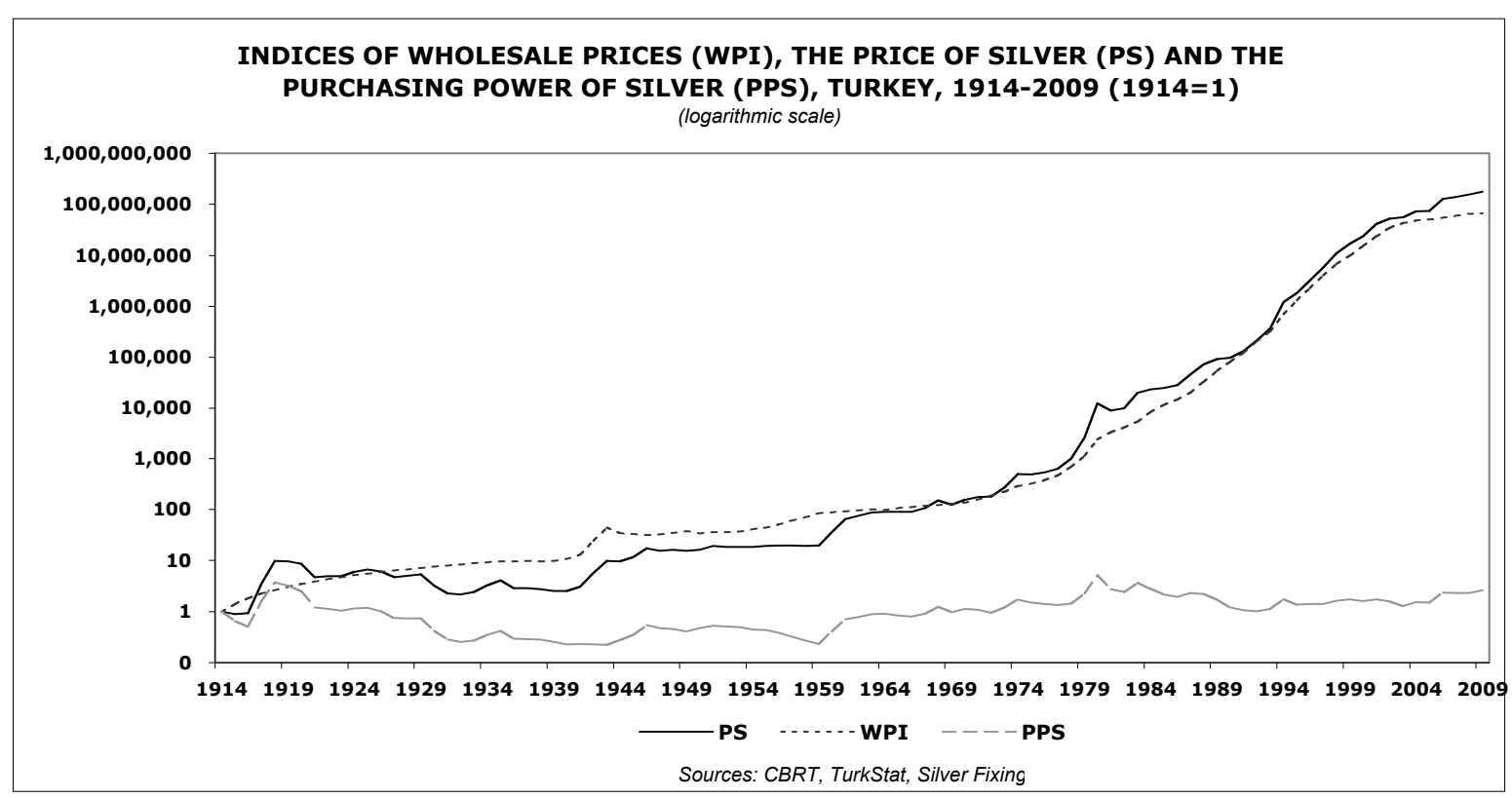

Figure 3. Indices for wholesale commodity prices, the price of silver and the purchasing power of silver, Turkey, 1914-2009

For the PS, we have reversed the redenomination of the new lira from the old paper lira, by adding back the six zeros cut in 2005. Meanwhile, we also included in figure 3, our WPI (CP), and since we calculated it by adopting a geometric mean, we shifted the base year to 1914 without fear of any distortion. Then, by deflating the PS for WPI we calculated the PPS (= PS / CP). We may clearly observe that an increase in the PS corresponds with an increase in CP. Moreover, the PPS has been constant throughout. Furthermore, as we shall subsequently explain in more detail, we took the WPI expressed in akches from 1469-1914, and multiplied the WPI in each year, by the value of akche in terms of silver in the same year, as reflected in the amount grams of pure silver (SC). This gave us wholesale prices expressed in grams of silver (WPIsc). The reciprocal of prices expressed in a precious metal provides the purchasing power of that metal, hence we may state that under the Ottomans, the same applies and 1/WPIsc $=$ PPS. Equally, under the Ottomans, the index for the nominal price of silver would be the reciprocal of the SC, but also PS = CP x PPS. Accordingly, we present the WPI, PS and PPS for the period $1469-1914$ in figure 4. 


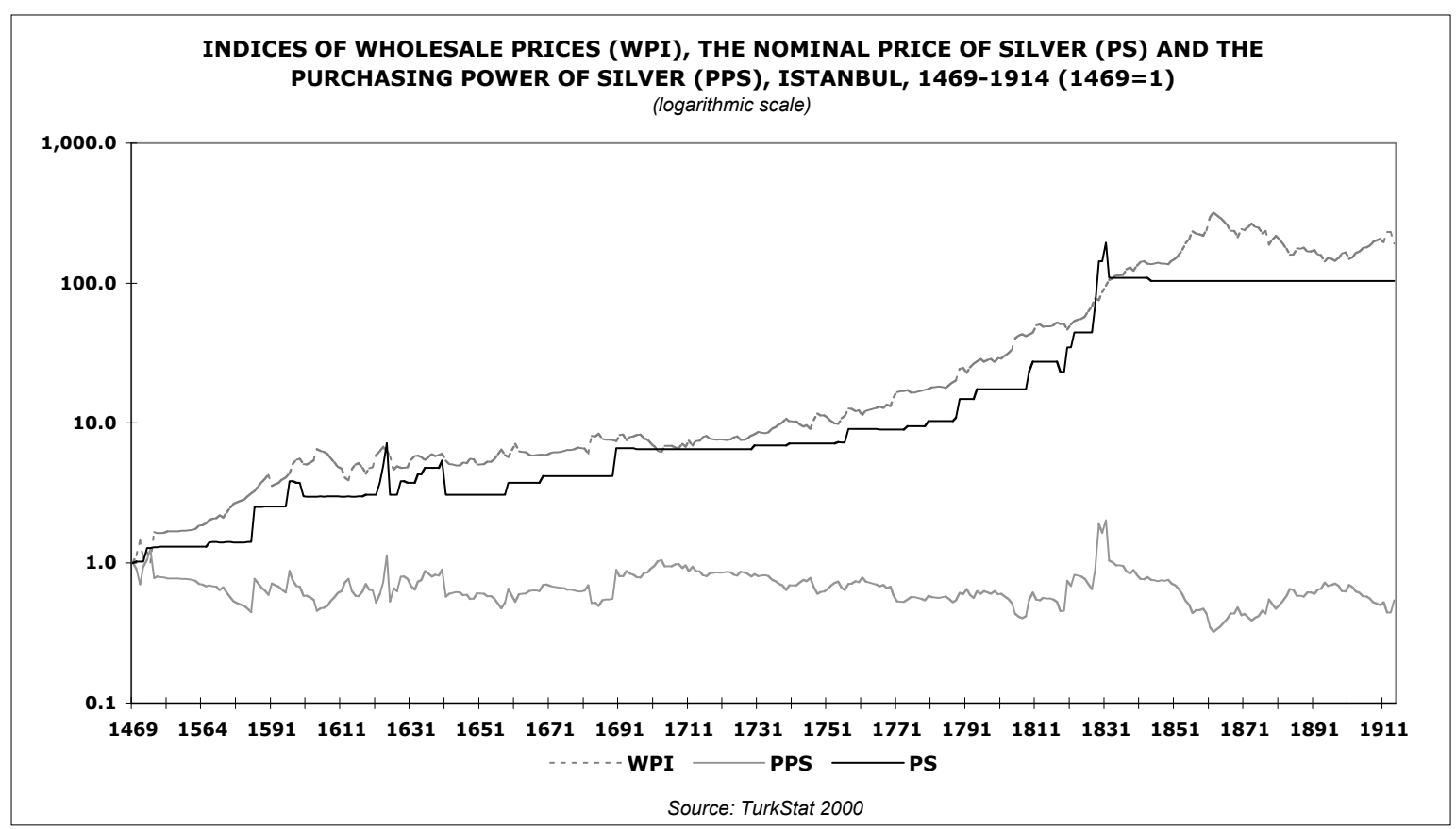

Figure 4. Indices for wholesale commodity prices, the price of silver and the purchasing power of silver, Istanbul, 1469-1914

Now we have an index of the PPS from 1469-1914 and an index of the PPS from 1914-2009, and by simply linking the two we have a combined PPS over the long term, from 1469-2009, which we present in figure 5 . Since, we also have our WPI from 1469-2009 we can therefore also calculate that, by implication, the PS must be a function of CP x PPS, which we also include in figure 5 for the period 1469-2009. The redeeming feature of both figures is the constant nature of the PPS over the long term. When no longer supported by a precious metal, the lira collapsed in value as reflected in the higher PS, and this has undermined the PPM or rather the purchasing power of the lira, since the exponential decay in the value of the lira caused by the excessive production of fiat money in relation to demand, the effect of which is an exponential rise in the price level.

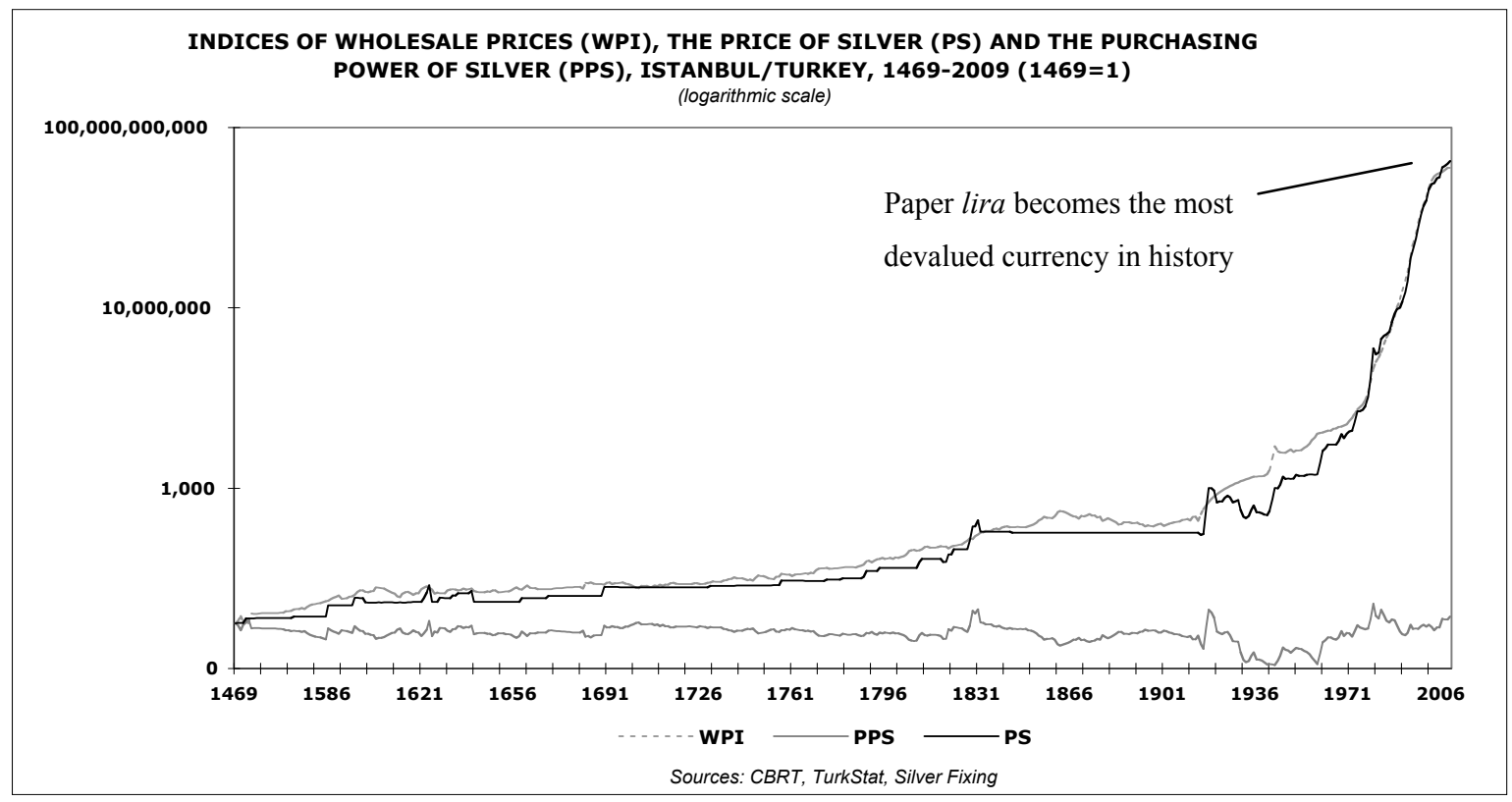

Figure 5. Indices for wholesale commodity prices, the price of silver and the purchasing power of silver, Istanbul/Turkey, 1469-2009 
In order to meet fiscal obligations derived from budget deficits the government was required to raise additional revenue, such as seigniorage from the mint as an alternative to raising taxes: however, debasement added to the nominal value of the currency, but almost always increased the price level which eliminated any increase in the real volume of coinage in circulation. If prices did not rise due to shortages of specie or for another reason (such as depopulation that would deflate agricultural prices), then trade was the equalizer: if prices, expressed in the weight of silver, became less in comparison to another region, the increased demand of those commodities would generate an influx of silver, thereby increasing the money supply and inflating prices (Pamuk, 2004, p. 460).

Since the obligations of the government were expressed in a terms of a monetary unit of account, a reduction in the silver content enabled the government to increase the amount it could mint from, and make payments with, a given amount of silver (Pamuk, 2004, p. 460). The government benefited form the first use of debased coinage to meet their short term fiscal requirements, and others also benefited such as borrowers and tenants paying fixed rents in cash, but many did not including creditors, the military, the bureaucracy, the scholars and teachers, indeed any employee on a fixed income, demanded an increase in salaries when they noticed the smaller sized coins, and the janissaries did just this with Mehmed II in 1844 (Pamuk, 2000, pp. 56-57).

The debasement of the standard Ottoman monetary unit of account, in terms of grams of pure silver (SC), was a significant determinant of increases in prices (WPI) over the long term, and the strong inverse relationship in nominal terms is captured in figure 6, with both axes in log scale so that the slope of the curve indicates the rate of change in debasement and nominal prices. We have also presented Pamuk's version of Ottoman consumer prices (CPI), in order to compare our WPI, and noticed that Pamuk's fixed-weight index, slightly over-states inflation, by his own admission (Pamuk, 2002, p. 299).

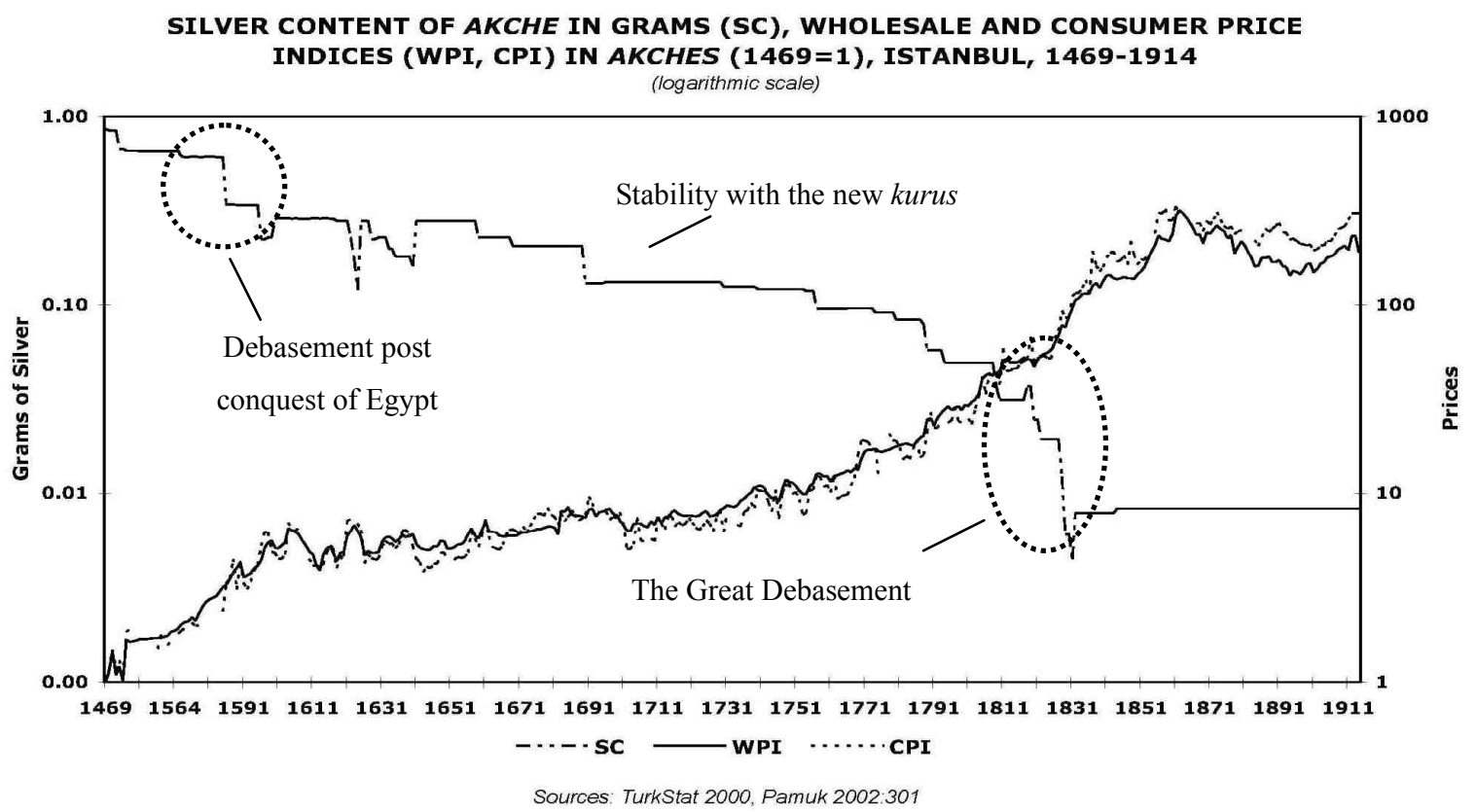

Figure 6. Silver content of the akche in grams and indices of wholesale and consumer prices in akches, Istanbul, 1469-1914

One way of demonstrating the relationship between debasements and prices is presented in figure 7, since PPM $=1 / \mathrm{P}$, so the purchasing power of the akche $(\mathrm{PPA})=1 / \mathrm{P}$, and we may observe the direct relationship between debasement and prices, by illustrating the correlation of the PPA and the silver content of the akche in grams of pure silver (SC). 


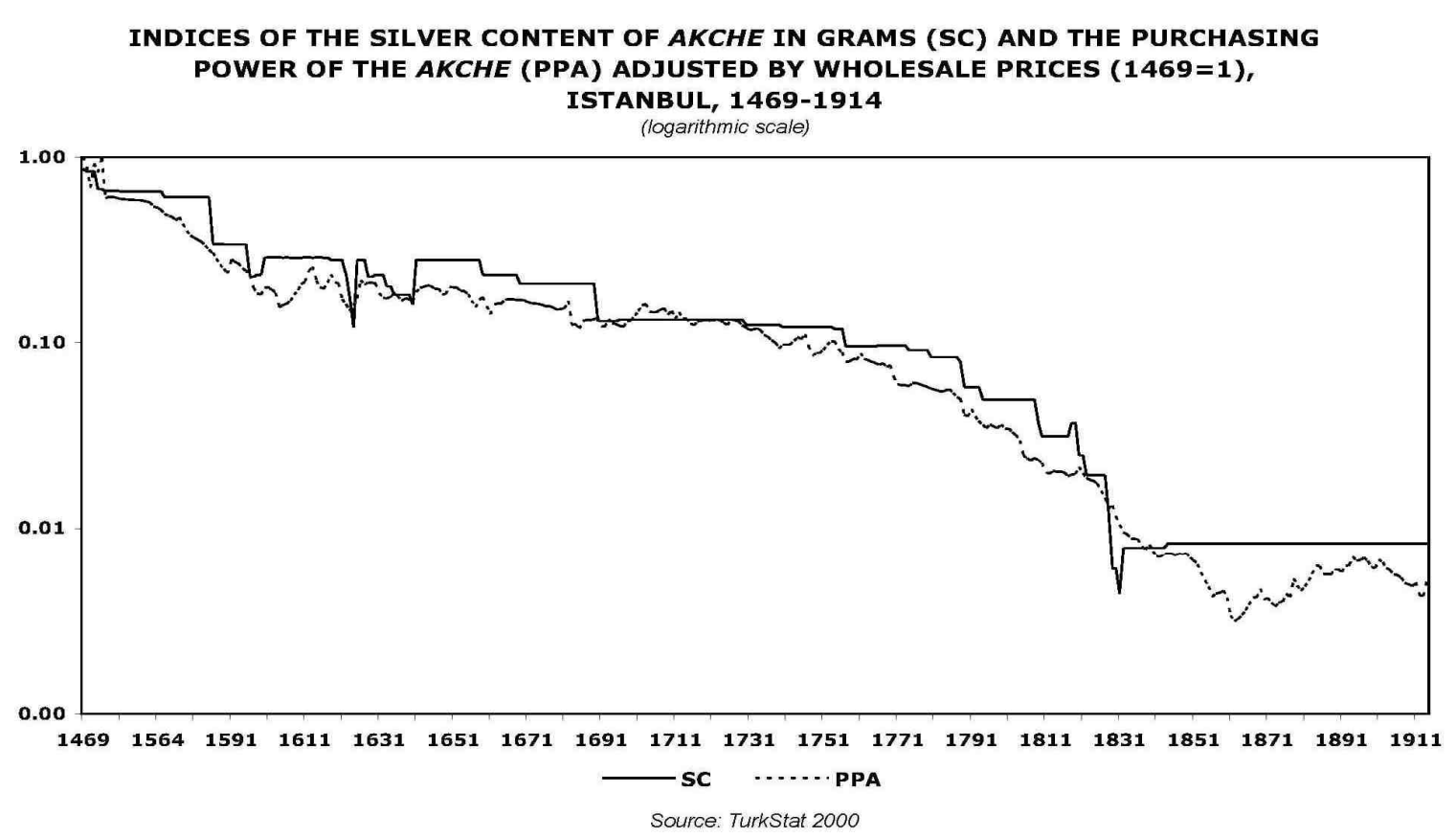

Figure 7. Indices of the silver content of the akche in grams and the purchasing power of the akche adjusted by wholesale prices, Istanbul, 1469-1914

Another way of more closely examining the relationship between debasements and prices, is to construct a wholesale commodity price index (WPI) expressed in terms of the weight of silver in grams or silver content of the akche (SC), where WPIs (in silver) = WPI x SC (figure 8 in linear scale), and over $4 \frac{1}{2}$ centuries, whilst nominal prices increased by 300 times, when expressed in silver, prices remained within a relatively narrow range of 1.0-3.0 revealing that debasement was the primary determinant of the increase in Ottoman prices.

WHOLESALE PRICE INDEX (WPI) IN GRAMS OF SILVER, ISTANBUL, 1469-1914 (1469=1) (linear scale)

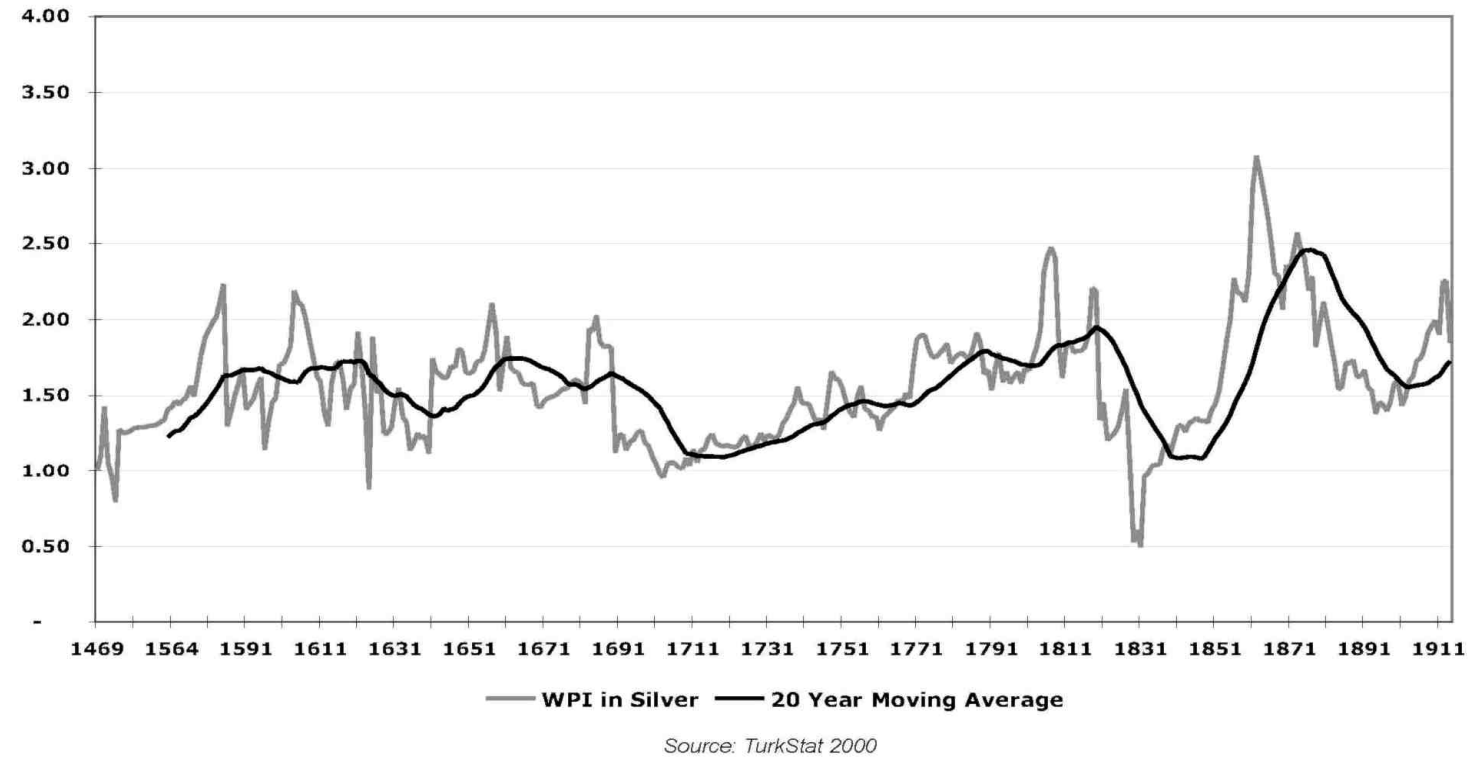

Figure 8. Wholesale commodity prices in grams of silver (linear scale), Istanbul, 1469-1914 
Figure 9 presents the same data in logarithmic scale to show the rate of change in prices in real terms, being a construct of nominal prices corrected by the rate of decay in the VM, and reflect what prices would have been had the VM been stable.

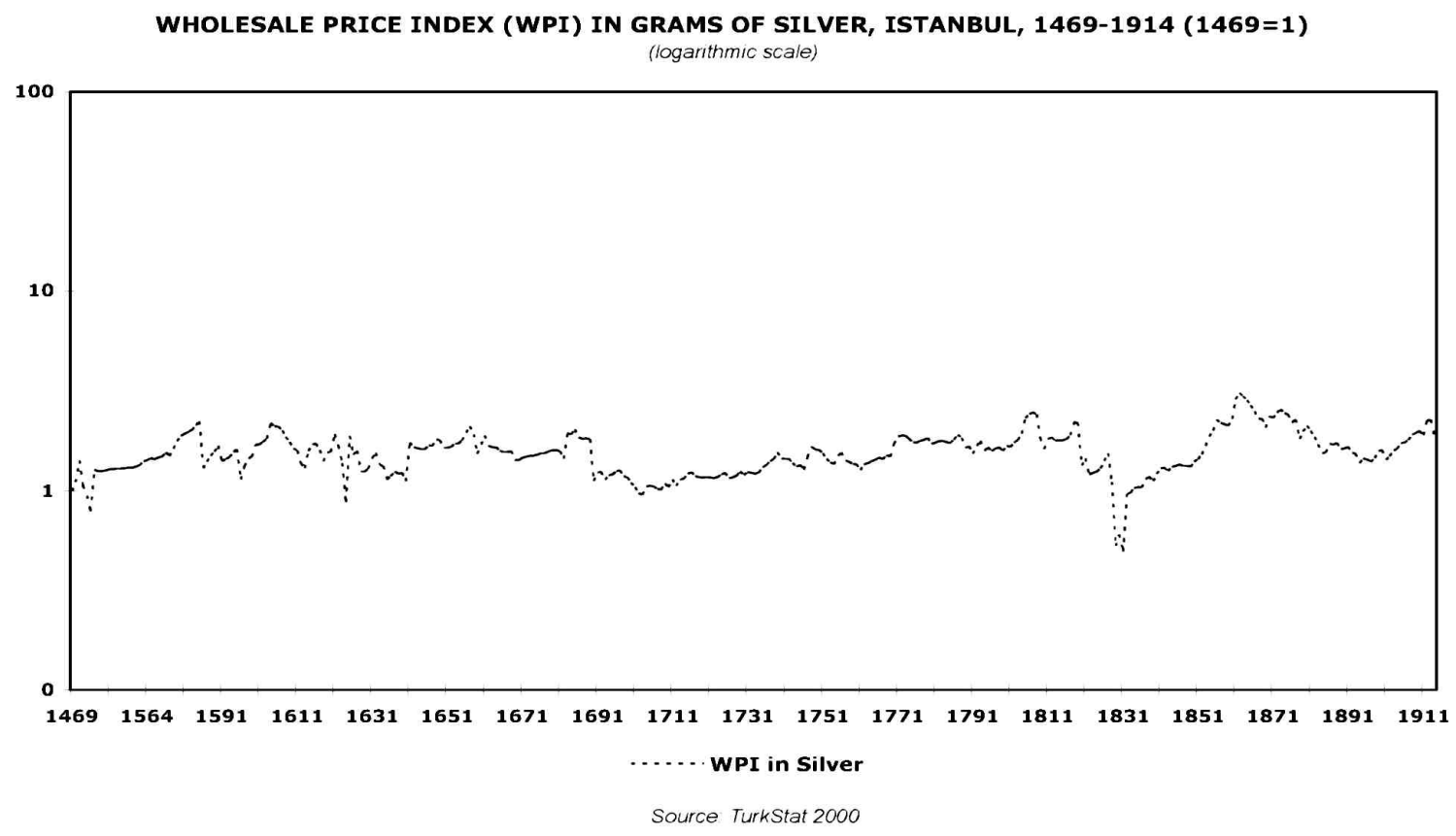

Figure 9. Wholesale commodity prices in grams of silver (logarithmic scale), Istanbul, 1469-1914

Of course, since silver is money, thus the PPS = 1/WPIs, we can show the impact that the VM has, not only on prices, but also by implication on the PPS (figure 10).

WHOLESALE PRICE INDEX (WPI) IN GRAMS OF SILVER AND THE PURCHASING POWER OF SILVER (PPS), ISTANBUL, 1469-1914 (1469=1) (logarithmic scale)

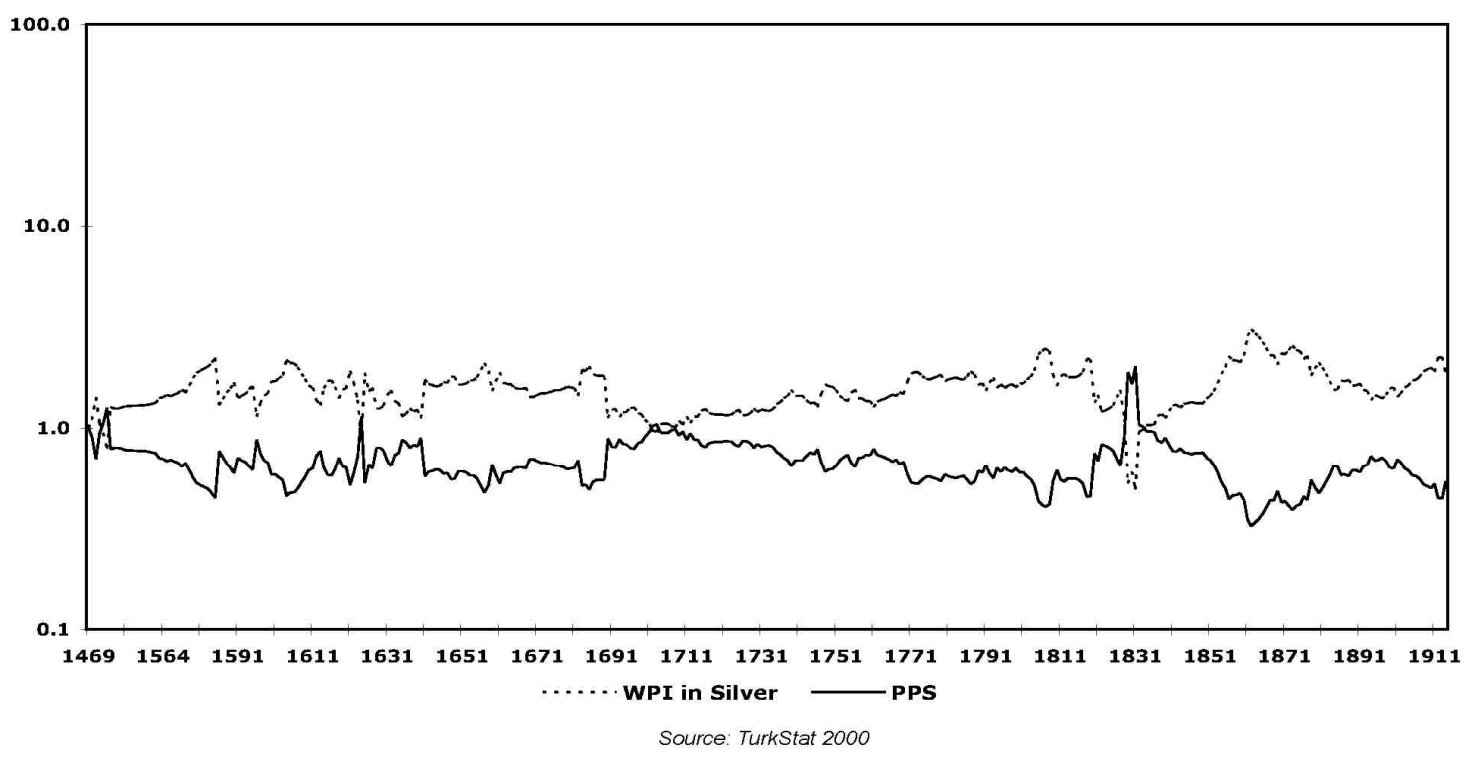

Figure 10. Wholesale commodity prices in grams of silver and the purchasing power of silver, Istanbul, 1469-1914

Given that the akche was a fixed weight of silver, debasement, particularly in the first-half of the $19^{\text {th }}$ century, 
saw a significant rise in inflation, resulting in a sharp drop in exchange rates (the silver kurus $=120$ akches: in $1788, £ 1=11$ kurus, by $1844 £ 1=110$ kurus, or a loss of $90 \%$ of its' value against a leading European currency). The largely Armenian (Christian) and Jewish moneychangers (sarrafs) which financed trade and guilds during the $18^{\text {th }}$ century, evolved into larger financiers, or Galata bankers, during the first-half of the $19^{\text {th }}$ century, but were 'bankers without banks', and early efforts at establishing banks in the 1840s failed due to the expansion in volume of paper notes, resulting in losses from a further deterioration in exchange rates (Pamuk, 2000, pp. 193,200,212). With no further reduction in silver content, prices continued to rise with the over-issuance of bank notes before stabilizing, and in figure 11 we re-present the SC of the akche as the instrinsic value of the Ottoman akche in terms of silver (OAs), together with the PPA and the PPS.

\section{INDICES OF THE SILVER CONTENT OF AKCHE IN GRAMS (SC) AND THE PURCHASING POWER OF THE AKCHE (PPA) ADJUSTED BY WHOLESALE PRICES (1469=1), ISTANBUL, 1469-1914 \\ (logarithmic scale)}

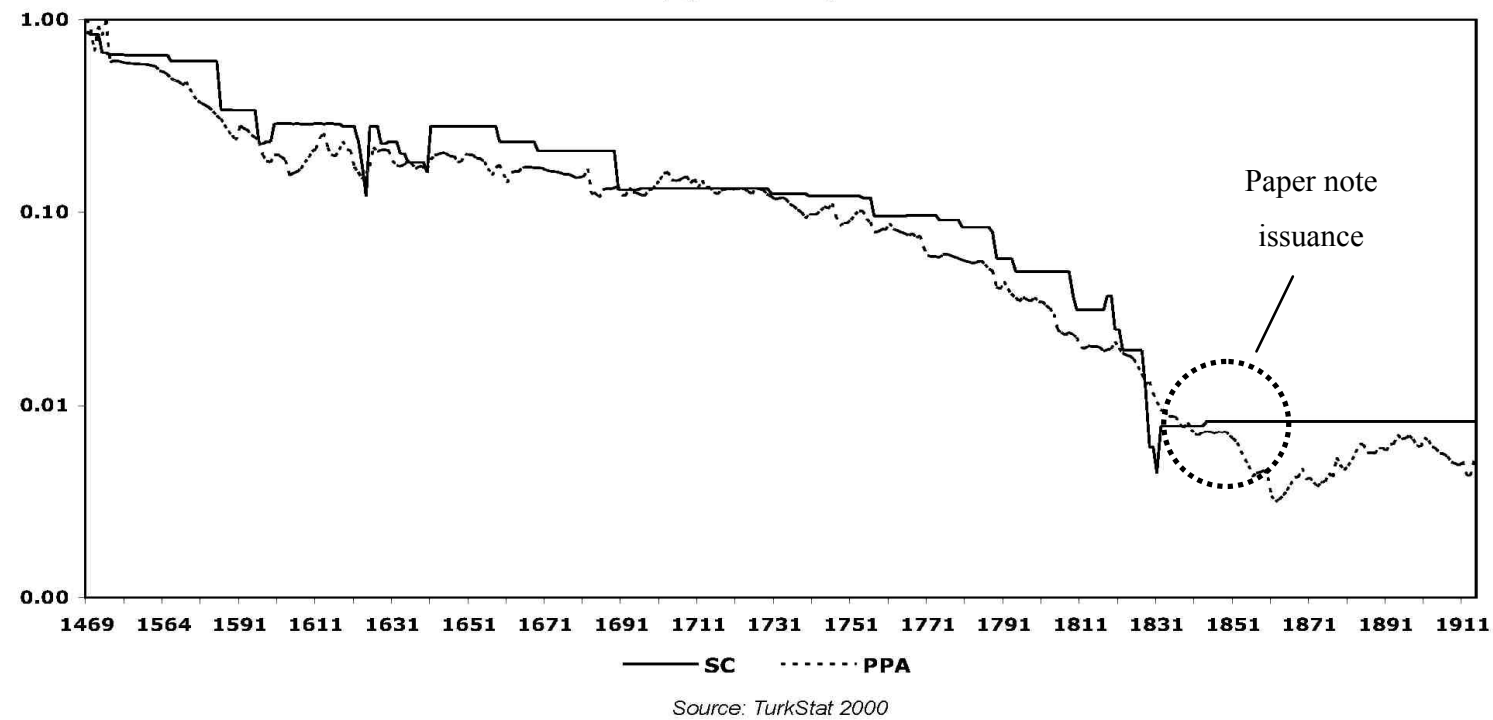

Figure 11. Indices of the value of the akche and the purchasing power of silver and the akche adjusted by wholesale prices, Istanbul, 1469-1914

From 1839 the Ottoman government issued paper notes (kiame) at 8\% interest, which circulated until 1862 (initially hand-written and then printed from 1842). In 1856 the Ottoman Bank was established and in 1863 it was given the monopoly to issue interest free, convertible bank notes (Saygili, 2009, pp. 153,154). The Ottoman Bank was founded in 1856 as a clearing-house for the Public Debt, based in London with branches in the Galata business district of Istanbul, Beirut, Izmir and Thessaloniki, with an initial capital of $£ 500,000$, as a joint-venture partnership between British interests (80,000 shares), the Banque de Paris et des Pays Bas (50,000 shares) and the Ottoman government (5,000 shares). In 1863 it became a state bank, renamed the Imperial Ottoman Bank, was granted a monopoly over issuing bank notes and operated as a private central bank. In 1875 it was conferred the role of Treasurer of the Empire, with authority over the finances of the state and as a clearing-house for the Public Debt Administration. British interests also owned other private central banks: the Imperial Bank of Persia in 1889 and the National Bank of Egypt in 1898.

The new gold lira coin was introduced in 1844 as the main monetary unit, weighing $7.216 \mathrm{~g}$ of 22/24 fineness containing $6.615 \mathrm{~g}$ of pure gold and equaled 100 kurus, each weighing $1.2 \mathrm{~g}$ containing $1 \mathrm{~g}$ of pure silver or $83.33 \%$ fine, thus a bimetallic standard of $6.615 \mathrm{~g}$ of gold to $100 \mathrm{~g}$ of silver existed, which implied a gold:silver ratio of 15.09 (Pamuk, 2000, pp. 191,209). With the outbreak of the Crimean War (1853-1856), the Ottoman Public Debt began in 1854, when the government first entered into loan contracts with European creditors. Soon new bond issues were required to service existing debt repayments. The accumulation of external debt from 1854-1877 (table 4) was unsustainable and led to a default by the Ottoman government in $1875 . \quad$ By 1875,127 million lira in loans had been advanced, but a total debt of 239 million lira (£217 million at 1.1 lira: £1) (Note 15) was now due, and with an annual income of 25.1 million lira, the total debt installment due that year was 30 million lira, which led to the government defaulting on its repayments (Saygili, 2009, p.155). 
Table 4. Ottoman foreign debt obtained between 1854 and 1877

\begin{tabular}{|c|c|c|c|c|c|c|}
\hline Year & $\begin{array}{l}\text { Nominal } \\
\text { Value (£) }\end{array}$ & $\begin{array}{l}\text { Actual Amount } \\
\text { Obtained (f) }\end{array}$ & $\begin{array}{c}\text { Interest } \\
(\%)\end{array}$ & $\begin{array}{l}\text { Rate of } \\
\text { Emission } \\
\text { (\%) }\end{array}$ & Reason for Debt & Intermediary \\
\hline 1854 & $3,000,000$ & $2,290,000$ & 6 & 80 & To finance Crimean War & Palmers-Goltschmidt \\
\hline 1855 & $5,000,000$ & $5,130,000$ & 4 & 102.6 & To finance Crimean War & Rothschilds \\
\hline 1858 & $5,000,000$ & $3,440,000$ & 6 & 76 & $\begin{array}{l}\text { To call in Bank notes from } \\
\text { circulation }\end{array}$ & Dent, Palmers \& Co. \\
\hline 1860 & $2,000,000$ & $1,230,000$ & 6 & 62.5 & Tithes & \\
\hline 1862 & $8,000,000$ & $5,150,000$ & 6 & 68 & $\begin{array}{l}\text { To call in Bank notes from } \\
\text { circulation and pay of } \\
\text { installments on short term debt }\end{array}$ & $\begin{array}{l}\text { Ottoman Bank and Devaux \& } \\
\text { Co. of London }\end{array}$ \\
\hline 1863 & $8,000,000$ & $4,980,000$ & 6 & 71 & $\begin{array}{l}\text { To call in Bank notes from } \\
\text { circulation and to coin money }\end{array}$ & $\begin{array}{l}\text { Ottoman Bank and Credit } \\
\text { Mobilier }\end{array}$ \\
\hline 1865 & $6,000,000$ & $3,700,000$ & 6 & 66 & $\begin{array}{l}\text { To pay off installments on } \\
\text { foreign (external) debt and } \\
\text { close budget deficit }\end{array}$ & $\begin{array}{l}\text { Ottoman Bank and Credit } \\
\text { Mobilier }\end{array}$ \\
\hline 1865 & $32,900,000$ & $19,800,000$ & 5 & 60 & $\begin{array}{l}\text { To convert domestic (internal) } \\
\text { debt of } £ 26.36 \text { million into } \\
\text { Government bonds with } 5 \% \\
\text { interest }\end{array}$ & $\begin{array}{l}\text { General Credit and Societe } \\
\text { General }\end{array}$ \\
\hline 1869 & $22,000,000$ & $11,560,000$ & 6 & 57 & $\begin{array}{l}\text { To pay off installments on short } \\
\text { term debt and close budget } \\
\text { deficit }\end{array}$ & Comptoire d'Escompte \\
\hline 1870 & $31,680,000$ & $9,540,000$ & 3 & 32.125 & To build railways in Rumelia & \\
\hline 1871 & $5,700,000$ & $4,050,000$ & 6 & 73 & $\begin{array}{l}\text { To pay off installments on short } \\
\text { term debt and close the budget } \\
\text { deficit }\end{array}$ & $\begin{array}{l}\text { Luois Kohensons and Dent, } \\
\text { Palmers \& Co. }\end{array}$ \\
\hline 1872 & $4,820,000$ & $4,650,000$ & 9 & 98.5 & To close the budget deficit & $\begin{array}{l}\text { Ottoman Bank and Credit } \\
\text { General }\end{array}$ \\
\hline 1873 & $20,230,000$ & $10,960,000$ & 5 & 54 & $\begin{array}{l}\text { To consolidate Government } \\
\text { bonds issued in } 1872\end{array}$ & \\
\hline 1873 & $27,780,000$ & $14,440,000$ & 6 & 54 & To close budget deficit & $\begin{array}{l}\text { Ottoman Bank and Credit } \\
\text { General }\end{array}$ \\
\hline 1874 & $40,000,000$ & $15,090,000$ & 5 & 40 & $\begin{array}{l}\text { To pay off installments on short } \\
\text { term debt }\end{array}$ & Ottoman Bank \\
\hline 1877 & $5,000,000$ & $2,600,000$ & 5 & 52 & $\begin{array}{l}\text { To finance the war against } \\
\text { Russia }\end{array}$ & $\begin{array}{l}\text { Ottoman Bank and Glyn, } \\
\text { Mills, Currie \& Co. of } \\
\text { London }\end{array}$ \\
\hline Total & $227,110,000$ & $118,610,000$ & & & & \\
\hline
\end{tabular}

Source: Saygili, 2009, p. 157

Under pressure from foreign governments, this led to the Muharrem Enactment on $20^{\text {th }}$ December 1881. As part 
of the Enactment, the debt was reduced, and the Ottoman Public Debt Administration (OPDA) was established, which began its operations in 1882. The European creditors became bondholders and were assigned rights to collect various tax and customs revenues of the Empire administered by the OPDA, which was a European-controlled organization essentially run by the creditors and employed 5,000 officials whom collected revenues that were then turned over to the creditors. In fact, external borrowing increased after the OPDA was established, given that it reflected the interests of the foreign creditors and they controlled all revenues and expenses of the Empire (Saygili, 2009, pp. 155-156).

With the finances and thus the politics of the Ottomans in the hands of a foreign agenda, the Ottomans were drawn into WWI on the side of the Central Powers (Austria-Germany), whom were defeated. The resulting default on debt and negotiations arising out of the Paris Conference of 1925 ensured that Turkey agreed to repay $62 \%$ of foreign debt borrowed prior 1912 and $77 \%$ on debt borrowed afterwards, the total being 84.6 million lira equivalent to about USD6 million when the Paris Agreement was signed in 1933. The foreign debt was finally repaid in 1954, 100 years after it first started (Saygili, 2009, p. 156).

Interestingly, by the end of WWI, the Ottomans owed $£ 100$ million to Rothschilds, the proceeds of which had been spent on railroads and other public utilities in Palestine, hence with the Ottoman government facing bankruptcy at the end of WWI, the creditors had substantial claims on Palestine, which was granted in theory through the Balfour Declaration of 1917, and in practice under the British Mandate in 1922 (Darms, 1930:186-188). The Mandate was a protectorate and not ownership, which occurred through direct ownership and management of the early Jewish settlements by the "Father of the Yishuv", Edmond James de Rothschild, whom in 1924 reorganized the Rosthchilds economic activity under the Palestine Jewish Colonization Association (PICA). Through acquisition of land and playing the role of a merchant bank in developing projects, PICA contributed significantly to the economic growth of the Jewish settlers, and by Edmond's death in 1934, it owned an immense estate: some 440,000 dunams, including 80,000 across the Jordan river (4.5 dunams = 1 acre), 30 settlements, and numerous ventures which included utilities (electrification, asphalt roads, deep-bore drilling for cultivation), commercial enterprises and agricultural development (Schama, 1978, pp. 247-270).

From a monetary perspective, with the declining price of silver, following de-monetization post-1873, and with a foreign debt denominated in gold, the gold standard was adopted in 1881 until 1914. Paper notes were first issued by the Ministry of Finance in 1912 and again in 1926 after the Caliphate was abolished in 1924. Following the adoption of paper money in the 1920s, 1 gold lira $=9$ paper lira; in 1946 a peg of 2.8 lira/dollar was adopted until 1960 when the lira was devalued to 9 lira/dollar; post Bretton Woods and in 2001 the lira was worth $1.65 \mathrm{Mn} /$ dollar, and revalued in 2005 by dividing the old lira by one million, thus eliminating the zeros, but not the cumulative transfer of wealth to the bankers through inflation. Following the transition period for the revaluation between 2005-2008, the new lira in 2009 is worth about 1.5 lira/dollar. The recent history of the Turkish lira, as the most devalued paper currency of all time, implied that bullion backing is required in the settlement of transactions.

In summary, we have presented the value of the Ottoman akche (OAs) in real terms in terms of silver as a function of the silver content in grams of pure silver (SC) thereby revealing the intrinsic value of the akche as a unit of account and measure of value over the long term. Equally, we have presented the purchasing power of money (PPM) in terms of the akche (PPA) in conjunction with the purchasing power of the lira (PPL), when adjusted for wholesale commodity prices (WPI). We have also demonstrated that the monetary policy of the Ottomans involved debasements of coinage, which reflected a reduction in the value of money (VM), as a result of an excessive increase in nominal money supply in relation to demand, the effect of which was an increase in the price level: this being a monetary theory of value. We have demonstrated that the reason for the increase in prices was indeed as a result of debasements, which decrease the value of the Ottoman akche (OAs) in terms of its silver content (SC), affecting the PPA and nominal WPI. By expressing prices in terms of silver, not only reveals a remarkably constant trend, but also adjusts prices in real terms to reveal what prices would have been if the value of money (VM) had been constant. With respect to figures 9 and 10, we can extend the series from 1469-1914 to 1469-2009 in figures 12 and 13. Notwithstanding the incredible volatility associated with the breakdown of money in the $20^{\text {th }}$ century, and the escalation of both WPI and PS under the fiat standard, we may observe the stability that a constant VM brings to prices when corrected for debasement or devaluation, in terms of a precious metal, in this case silver. 


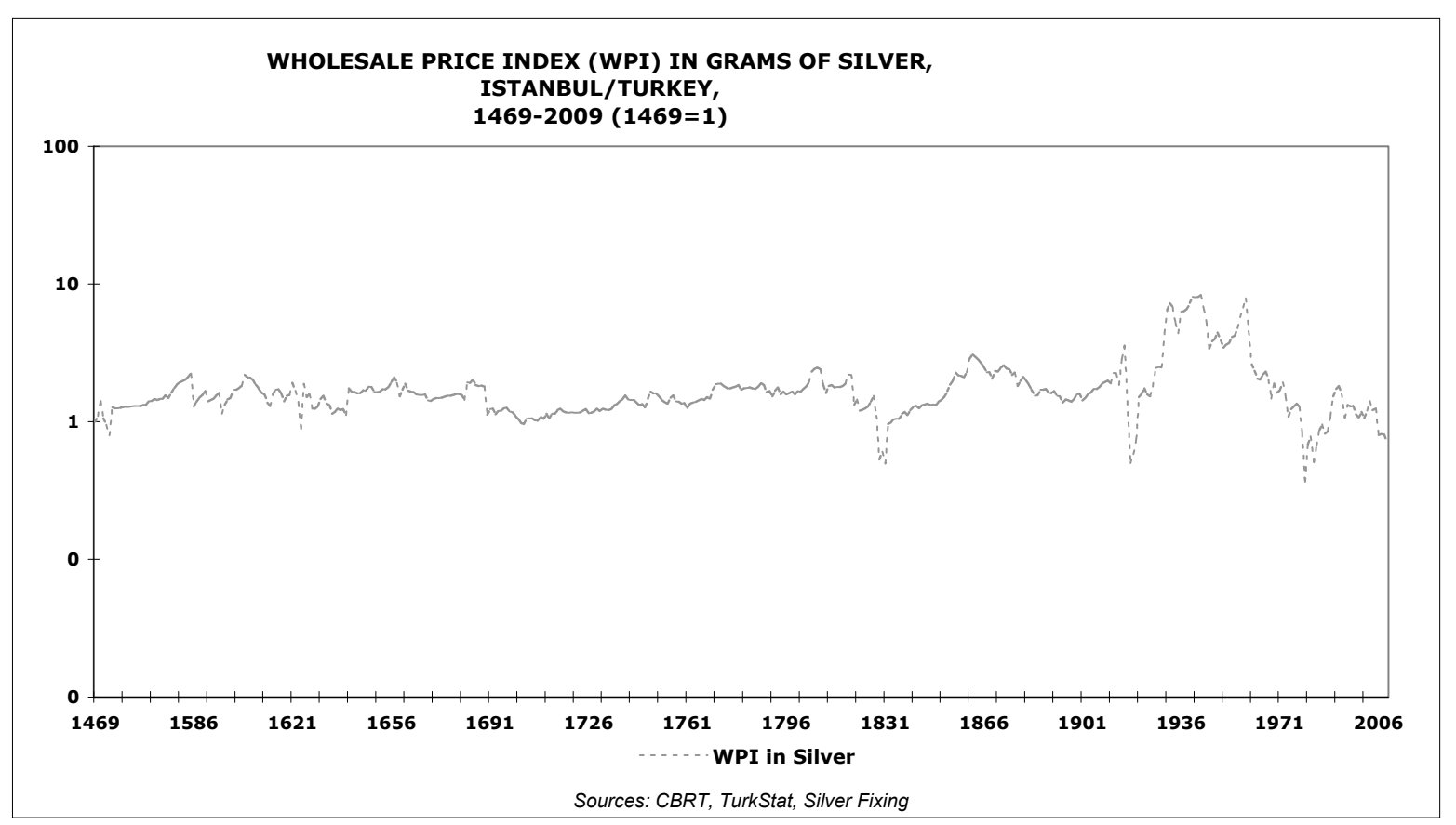

Figure 12. Wholesale commodity prices in grams of silver, Istanbul/Turkey, 1469-2009

And again, since silver is money, and the reciprocal of prices expressed in their bullion equivalents reveals the purchasing power of bullion, so PPS = 1/WPIs, and we can once again prove that by stabilizing the VM we can not only stabilize prices but also by implication so too is the PPS constant over the long term, which may be appreciated further given that PPS $\mathrm{x}$ WPIs $=1$.

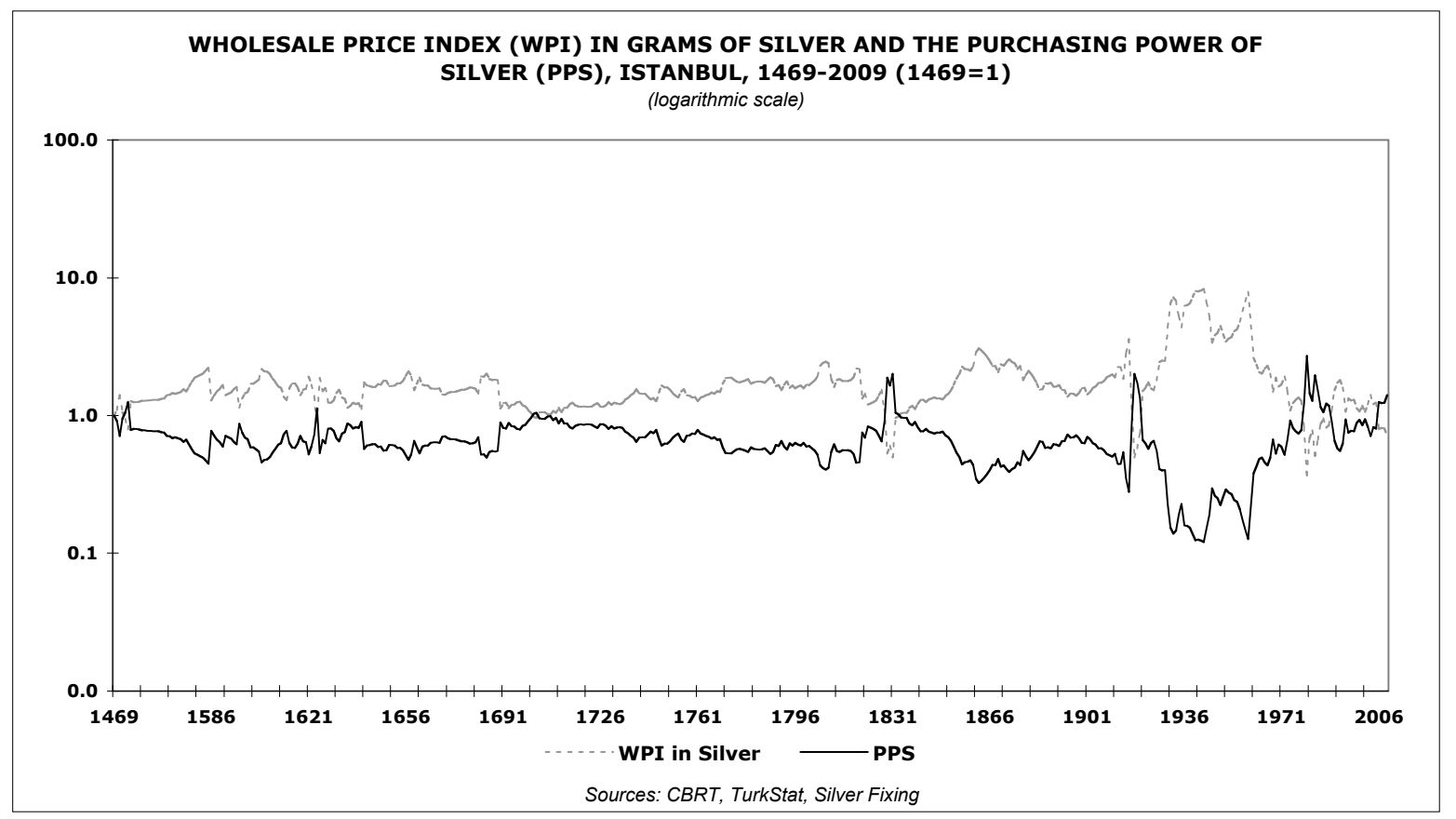

Figure 13. Wholesale commodity prices in grams of silver and the purchasing power of silver, Istanbul, 1469-2009

Although the correlation between the PS and WPI from 1469-2009 is 0.98 , implying that a decrease in the VM 
(reflected in a higher PS) is strongly correlated with higher WPI, but it does not reveal causality, or how to correct the VM and the associated impact upon WPI. With empirical evidence and statistics, this paper has detailed the necessary adjustment regarding the VM and the PPM. By expressing real prices, in terms of silver, and then multiply real prices by the PPS (and the same would apply for the PPG) we discover that WPIs $x$ PPS (or WPIg $\mathrm{x} P \mathrm{PG})=1$. Hence, inflation or deflation are purely monetary phenomena, and any decrease in the VM is proportional to an increase in nominal WPI. With a stable currency, real prices (WPIs, WPIg) and real money (PPS, PPG) vary in the short term, but revolve around a secular trend that is constant over the long term.

In assessing short-term volatility, prices expressed in real terms reveal factors associated with other than monetary distortion. Such factors can include political, social and economic issues, the latter including shocks to the economy due to the monetary system resulting in a mis-allocation of resources. In table 5 , the silver akche mono-metallic Ottoman unit of account suffered from debasement by the authorities that would affect both long term stability and short term volatility, resulting in a loss of purchasing power, that saw it replaced by the larger kurus in 1690. During the first hundred years of the kurus from 1960-1790 the performance was much better with long-term stability averaging $1.3 \%$ and short-term volatility averaging $3.8 \%$ combining to provide the best overall performance in terms of our stability ranking. However, serious debasement would return in the $19^{\text {th }}$ century, which also witnessed substantial increase in both internal and external borrowings. The long-term stability from 1469-1844 averaged a $\%$ change in nominal wholesale prices.

Table 5. Wholesale price index, Turkey: long-term stability and short-term volatility

\begin{tabular}{|c|c|c|c|c|c|}
\hline Period & Monetary System & $\begin{array}{c}\text { Long-Term } \\
\text { Stability }\end{array}$ & $\begin{array}{c}\text { Short-Term } \\
\text { Volatility }\end{array}$ & $\begin{array}{c}\text { Stability } \\
\text { Rank }\end{array}$ & Comments \\
\hline $1469-1690$ & $\begin{array}{l}\text { monometallic silver commodity } \\
\text { money (includes notable } \\
\text { debasements in late } 15^{\text {th }} \text { and } 16^{\text {th }} \\
\text { centuries) }\end{array}$ & $1.8 \%$ & $7.7 \%$ & 4 & akche (initially 1/4 dirham) \\
\hline $1690-1790$ & $\begin{array}{l}\text { monometallic silver commodity } \\
\text { money (kurus replaces the akche) }\end{array}$ & $1.3 \%$ & $3.8 \%$ & 1 & kurus $(=120$ akches $)$ ex 1690 \\
\hline 1790-1844 & $\begin{array}{l}\text { monometallic silver commodity } \\
\text { money (includes the Great } \\
\text { Debasement 1808-1834) }\end{array}$ & $3.3 \%$ & $4.1 \%$ & 3 & $\begin{array}{c}\text { kurus (= } 120 \text { akches) ex 1690: } \\
\text { Galatan bankers increased internal } \\
\text { borrowings }\end{array}$ \\
\hline 1844-1914 & $\begin{array}{l}\text { domestic bimetallic standard from } \\
1844 \text { (gold lira introduced) \& } \\
\text { international gold standard de jure } \\
\text { from } 1881\end{array}$ & $0.7 \%$ & $4.5 \%$ & 2 & $\begin{array}{l}\text { fractional reserve bullion standard } \\
\text { with Ottoman Bank; external } \\
\text { borrowings increase }\end{array}$ \\
\hline 1914-1944 & $\begin{array}{l}\text { inter-war paper standard (WWI } \\
\text { effectively saw Turkey depart from } \\
\text { the gold standard) }\end{array}$ & $13.1 \%$ & $19.9 \%$ & 6 & $\begin{array}{l}\text { inflationary WWI, War of } \\
\text { Independence; paper lira from } \\
\text { 1920s; inflationary WWII (despite } \\
\text { neutrality) }\end{array}$ \\
\hline 1944-1971 & $\begin{array}{c}\text { Bretton Woods gold exchange } \\
\text { standard }\end{array}$ & $5.1 \%$ & $6.0 \%$ & 5 & $\begin{array}{l}\text { fractional reserve gold exchange } \\
\text { standard }\end{array}$ \\
\hline 1971-2009 & international fiat paper standard & $42.5 \%$ & $27.9 \%$ & 7 & fractional reserve debt as money \\
\hline
\end{tabular}

The bimetallic and international gold standards provided for greater stability, as England was already on a the gold standard since 1717 (officially from 1816), that saw the Ottomans move from a silver commodity standard, to a bimetallic standard, then to gold standard, since silver was de-monetized in the U.S. from 1873, which ensured a long term secular decline in prices up to WWI. The inflationary production of paper money during and immediately after WWI effectively saw Turkey depart from the gold standard, resulting in poor inter-war monetary performance that would only recover during the Bretton Woods system. Absent of any bullion backing 
with the international monetary system after 1971, the lira descended into out-right instability over the long term with the change in wholesale prices averaging $42.5 \%$ up to 2009 ; in contrast, when prices are expressed in silver (WPIs), the long term stability reveals a modest long term increase in prices from 1469-2009 of an average annual change of $1.3 \%$ (0.9\% from $1469-1914)$.

\section{Conclusion}

In the preceding sections, we have analyzed the VM and PPM in Turkey over 541 years from 1469-2009. Our findings found that silver retains its purchasing power over the long term, whilst paper money in terms of the Turkish lira, failed a basic function of money in retaining its store of value. This conclusion mirrors the analysis on English data presented by Abdullah (March 2013). Whilst, we agree with Jastram that, "We have escaped from clipped, debased and manipulated coinage into manipulated, debased and politicized paper - not much of an exchange. World stability rests on money" (Jastram, 1981, p. 158), we do not agree that the solution is to abandon altogether a precious metal that is so clearly beneficial to mankind over the long term. This paper has confirmed that debasement and devaluation have been the primary cause in the decline of the VM and PPM. Hence a monetary theory of value stipulates that a reduction in the value of money (reflected in its rate of exchange with a precious metal), as a result of an excessive increase in nominal money supply in relation to demand, the effect of which is an increase in nominal prices. Prices move in proportion to the rate of debasement and inversely with the gold or silver content of money. By correcting any change in the VM, we obtain real prices in gold or silver, the reciprocal of which is the PPG or PPS, such that real prices, real gold and real silver vary over the short term but are constant over the long term, and for "a currency, to be perfect, [it] should be absolutely invariable in value" (Ricardo, 1816, pp. 13-14).

As previously mentioned, the VM is different from the PPM and what a currency can buy at a particular moment in time. Changes in the PPM can occur from either the demand and supply of commodities and also from the supply and demand of money. A price of a commodity reflects the value in exchange, and the WPI is affected by the VM. The price is a measure of value, or rather the ratio of two values, the ratio of the demand and supply of commodities and also the supply and demand of money. A decrease in the VM reflects debasement and devaluation of the circulating medium, as a result of an excessive supply of money in relation to demand, the effect of which is an increase in nominal prices. We can therefore deduce that price changes from inflation and deflation involve monetary distortions, which can be distinguished from price changes due to non-monetary reasons. Indeed, the historical meaning of inflation meant an inflated PG due to the excessive production of redeemable bank notes under a gold standard, rather than price inflation for commodities.

$$
\text { Price of a commodity }=\frac{\frac{\text { Demand for a commodity }}{\text { Supply of a commodity }}}{\frac{\text { Demand for money }}{\text { Supply of money }}}
$$

In (6), when the VM in the denominator is constant then the value of the numerator might vary (as it should) over the short term, but would remain constant over the long term. Prices are supposed to change in order to organize an economy. Monetary policy should not target stable prices by managing the devaluation of the VM and PPM, but should maintain a stable currency, free from manipulation by monetary authorities, in order to obtain a stable PPM and thus stable WPI over the long term. The reality is that the equalizer to changes in prices and the value of money and its purchasing power is through free and fair trade, and by determining money through its intrinsic not extrinsic value, nor monopolizing the supply of money, nor monopolizing or controlling trade. The medium of exchange should be of high intrinsic value and be an instrument of transfer only, not created out of nothing and charged at a price.

Our empirical evidence has demonstrated that the classical quantity theory and the mercantilist Keynesian purchasing power theory have both heavily influenced modern monetary policy, involving a medium of exchange that is anchored to debt rather than a precious metal. These monetary theories collapse in the presence a monetary theory of value, especially under the fiat standard, which has witnessed an exponential decay in the $\mathrm{VM}$, as a result of an excessive supply of money through debt and money creation, in relation to demand, the effect of which has involved an exponential increase in nominal prices, but when the loss in the value of money has been corrected, we discover that real prices, in terms of gold or silver, are both low and constant. Absent of a well maintained circulating specie in the form of pure gold and silver, societies are required to lower their standard of living, through increased prices, involving the transfer of wealth to the issuers of money (in the form of the fractional reserve banking system): "the decrease in purchasing power incurred by holders of money due 
to inflation imparts gains to the issuers of money" (Reubling, 1975, p. 22), that involves wealth "confiscation through inflation. There is no safe store of value...no way for the owners of wealth to protect themselves... Gold [or silver] stands in the way of this insidious process" (Greenspan, 1966).

\section{References}

[BHI; Brown-Hopkins Index], Brown, H. P., \& Hopkins, S. V. (1956, November). Seven Centuries of the Prices of Consumables, Compared with Builders' Wage-Rates, Economica 23, pp. 296-314, Brown-Hopkins Index reprinted in Carus-Wilson (1962), Vol. 2, pp. 179-196, and with additional appendix in Brown, H. P., \& Hopkins, S. V. (1981), A Perspective of Wages and Prices. London: Methuen, pp. 13-59.

[ILO-PPI] ILO. (2004). Producer Price Index Manual: Theory and Practice. Geneva: International Labour Office.

Abdullah, A. (2013, March). Examining the Value of Money in England Over the Long Term (1259-2009). International Journal of Economics and Finance, 5(3), 73-89. http://dx.doi.org/10.5539/ijef.v5n3p73

Allen, R. C. (2001). The Great Divergence in European Wages and Prices from the Middle Ages to the First World War. Explorations in Economic History, 38(2), 411-447. http://dx.doi.org/10.1006/exeh.2001.0775

Al-Maqrizi, A. A. (1994). Mamluk Economics, a Study and Translation of Al-Maqrizi's Ighathah (Kitab Ighathat al-Ummah bi-Kashf al-Ghummah) (Book of Aiding the Ummah by Investigating the Depression), first published in Egypt in 1405, trans. by Adel Allouche, Salt Lake City: University of Utah Press

Beveridge, W. (1965). Prices and Wages in England from the Twelfth to the Nineteenth Century, Vol.1 Price Tables: Mercantile Era [1550-1830], first edition published 1939, London: Longmans Green \& Co., re-published London: Frank Cass \& Co. Ltd

Clarke, T. G. (1974). Silver. Bureau of Mines / Minerals Yearbook, Metals, Minerals and Fuels. Retrieved from http://digicoll.library.wisc.edu/cgi-bin/EcoNatRes/EcoNatRes-idx?type=article\&did=EcoNatRes.MinYB19 74v1.CKlingman3\&id=EcoNatRes.MinYB1974v1\&isize $=\mathrm{M}$

Darms, A. (1930). The Delusion of British-Israelism. New York: Loizeaux Brothers.

Fisher, I. (1911). The Purchasing Power of Money. New York: Macmillan.

Fisher, I. (1922). The Making of Index Numbers: A Study of Their Varieties, Tests, and Reliability. Boston: Houghton Mifflin Company, reprinted by Whitefish MT: Kessinger Publishing, 2008.

Frey, A. R. (1973). A Dictionary of Numismatic Terms. New York: American Numismatic Society, 1917; also published New York, Barnes \& Noble, 1947; and London, Spink \& Son.

Greenspan, A. (1966). "Gold and Economic Freedom", originally published in The Objectivist Newsletter, http://www.321gold.com/fed/greenspan/1966.html Accessed 20 July 2013, and also published in Rand, A., 1967, Capitalism: The Unknown Ideal, New York: Signet, p. 101.

Hanioglu, M. S. (2008). A Brief History of the Late Ottoman Empire. Princeton: Princeton University Press

Jastram, R. W. (1977). The Golden Constant, the English and American Experience 1560-1976, originally published New York: John Wiley \& Sons, published with updated material 1560-2007 by Leyland, J. (2009). London: Edward Elgar Publishing.

Jastram, R. W. (1981). Silver, the Restless Metal. New York: John Wily \& Sons.

Kabaklarh, N. (2007). Ottoman Copper Coins Minted in Tira 1411-1516. Istanbul: Tire Belediyesi.

Keynes, J. M. (1958). A Treatise on Money, Vol.1 The Pure Theory of Money, Vol.2 The Applied Theory of Money, originally published in 1930, reprinted London: Macmillan.

Mitchell, W. C. (1965). The Making and Using of Index Numbers, originally published in 1915 in Bulletin 173, Bureau of Labor Statistics, revised in 1921 and reprinted in 1938 in Bulletin 656, Bureau of Labor Statistics, reprinted New York: Augustus M. Kelley.

Pamuk, S. (1995). Long term trends in urban wages in Turkey 1850-1990. In P. Scholliers, \& V. Zamagni (Eds.), Labour's Reward: Real Wages and Economic Change in $19^{\text {th }}$ and $20^{\text {th }}$ Century Europe (Ch. 6, pp. 89-105). London: Edward Elgar Publishing.

Pamuk, S. (2000). A Monetary History of the Ottoman Empire. Cambridge: Cambridge University Press.

Pamuk, S. (2004a). Money in the Ottoman Empire 1326-1914, Evolution of the Ottoman Monetary System. In H. Inalcik, \& D. Quataert (Eds.), An Economic and Social History of the Ottoman Empire Volume 2 1600-1914. 
Cambridge: Cambridge University Press.

Pamuk, S. (2004b, August). Prices in the Ottoman Empire 1469-1914. International Journal of Middle East Studies, 36(3), 451-468.

Pamuk, S., \& Ozmucur, S. (2002, June). Real Wages and Standards of Living in the Ottoman Empire, 1489-1914. The Journal of Economic History, 62(2), 293-321.

Reubling, C. E. (1975, February). Financing Government through Monetary Expansion and Inflation. Federal Reserve Bank of St. Louis, Review, 15-23.

Ricardo, D. (1816). Proposals for an economical and secure currency: With observations on the profits of the Bank of England, as they regard the public and the proprietors of bank stock (2nd ed.). London: John Murray

Ricardo, D. (2004). The Principles of Political Economy and Taxation, originally published in 1817, 3rd edition published 1821, re-published London: J.M. Dent \& Sons 1911, re-printed New York: Dover Publications.

Rothbard, M. N. (1983). The Mystery of Banking. New York: Richardson \& Snyder.

Schama, S. (1978). Two Rothschilds and the Land of Israel. New York: Alfred A. Knopf.

Scholem, G. (1978). Kabbalah. New York: Meridian.

Walsh, C. M. (1901). The Measurement of General Exchange-Value. London: Macmillan.

Warren, G. F., \& Pearson, F. A. (1935). Gold and Prices. New York: John Wiley \& Sons.

\section{Notes}

Note 1. TurkStat price data was prepared by Sevket Pamuk, whom also has presented the data in a number of highly regarded academic papers and books on Ottoman monetary and price history. Pamuk holds the Chair of Contemporary Turkish Studies at the European Institute, London School of Economics and Political Science and is a leading economic historian of the Ottoman Empire, the Middle East and modern Turkey.

Note 2. The BHI is a retail price index developed by Brown and Hopkins (BHI, 1956, 1981, p. 28-31), which adopted a weighted arithmetic mean index for retail prices that was designed as a cost-of-living index.

Note 3. TurkStats (2000, pp. 12-18) also in Pamuk (1995, 2000, 2002, 2004a,b) includes the official weights and fineness of Ottoman coins as well as the silver content in grams of the main Ottoman monetary unit of account, the akche, with silver content derived from the akche 1469-1690 and from the kurus 1690-1914, basis 120 akche to 1 kurus (TurkStats, 2000, p. 7, c.f. Pamuk, 2000, pp. 136,163,237-8; 2004a, 2, p. 697).

Note 4. The Mamluks devalued the $4.25 \mathrm{~g}$ dinar by $20 \%$ in $829 \mathrm{H} / 1425$ to the $3.41 \mathrm{~g}$ al-Ashrafi (named after Barsbay, al-Malik al-Ashraf), which was slightly lighter than the Venetian ducat and became the standard Mamluk gold coin. The first Ottoman gold coin, the Sultani, was minted in $882 \mathrm{H} / 1477$ and was exchanged at par to the ducat, reflecting the latter's popularity as a trade coin. From 100 Tabriz mithqals 129 Sultanis were initially minted weighing 3.572g of 0.997 fine (Pamuk, 2000, p. 63). The Tabriz mithqal $=24$ karats $=1.5$ dirhams. Each karat $=4$ habbah of wheat. Since the grain of wheat weighs $0.048 \mathrm{~g}$, the karat $=0.192 \mathrm{~g}$, the Tabriz mithqal $=96$ habbahs $\times 0.048=4.608 \mathrm{~g}$, and the dirham $=4.608 / 1.5=3.072 \mathrm{~g}$ (Kabaklarh, 2007:33). In 1477, from 100 mithqals $=100 \times 4.608 / 129=3.572 \mathrm{~g}$ Sultani. From 100 mithqals, the weight was reduced in 1526 to 130 sultanis $(3.545 \mathrm{~g})$, and in 1564 to 131 sultanis $(3.518 \mathrm{~g})$, with the 0.997 fineness unchanged (Pamuk, 2000, p. 63). The Venetian ducat (zecchino or sequin) $=3.4909 \mathrm{~g}$ of 0.986 fineness or $0.1107 /$ troy oz actual gold weight $(3.4909 \times 0.986 / 31.103)$ comprised 54 troy grains and was first minted in 1284, adopting similar standards to the florin of Florence which was struck in 1252.

Note 5. In 1844 the new gold lira was introduced as the main monetary unit, weighing 7.216g of 22/24 fineness containing $6.615 \mathrm{~g}$ of pure gold and equaled 100 kurus, each weighing $1.2 \mathrm{~g}$ containing $1 \mathrm{~g}$ of pure silver or $83.33 \%$ fine, thus a bimetallic standard of $6.615 \mathrm{~g}$ of gold to $100 \mathrm{~g}$ of silver, implied a gold:silver ratio of 15.09 (Pamuk, 2000, pp. 191,209).

Note 6 . In 1690 the silver zolota weighing 6 dirhams or $19.2 \mathrm{~g}$ and $60 \%$ silver was minted, and in 1703 the silver kurus (piastre) weighing 8 dirhams or $25.6 \mathrm{~g}$ with $60 \%$ silver was minted: 1 silver kurus $=40$ para $=120$ akche, and 1 zolota $=3 / 4$ of a kurus or 90 akches: the kurus and zolota were used in larger transactions and the para and akche for smaller ones (Pamuk 2000, pp. 160, 2004 2:979,n.55).

Note 7. The Ottomans minted their first silver coin in 1326, the akche weighing $1.152 \mathrm{~g}$. It was supposed to be 
struck from pure (halis ayar) silver (Pamuk, 2000, p. 46), whilst in practice the Ottomans typically achieved a fineness of 23-231/2 carats (Kabaklarh, 2007, p. 36). The akche was $1 / 4^{\text {th }}$ of the Tabriz mithqal or 6 karats $=6 \mathrm{x}$ $0.192=1.152 \mathrm{~g}$ and from 100 Tabriz mithqals 400 akche were minted $(100 \mathrm{x} 4.608 / 1.152)$.

Note 8. From 1914 the annual average Turkish price of silver is the USD price converted into Turkish lira at the prevailing exchange rates from the Central Bank of Turkey. Sources for U.S silver prices: USGS prices per FTO to 5 decimals are available back to 1874 as per Minerals Yearbook (Clarke, 1974, p. 1196) with Mint Reports as the source. Warren and Pearson provide prices of silver bars at New York from 1874-1934 in USD per FTO (3 decimal places), derived from the U.S. Treasury from 1874-89, prices from 1890-34 were derived from the Course of Wholesale Prices 1890-1901, Bulletin of the Department of Labor, No.39, pp. 406-7, March 1902, and following issues (Warren, 1935, p. 257). Jastram also provides prices from 1925-1975 with source as Bureau of Mines (USGS) Minerals Yearbooks (Jastram, 1981, pp. 164-188,204-5). From 1968 the London Bullion Market Association (LBMA) quote USD silver price data from London Silver Market Fixing Ltd. Following the adoption of paper money in the 1920s, 1 gold lira $=9$ paper lira; in 1946 a peg of 2.8 lira/dollar was adopted until 1960 when the lira was devalued to 9 lira/dollar; post Bretton Woods and by 1971 the lira exchanged for 14.85 dollars, but by 2001 the lira was worth $1.65 \mathrm{Mn}$ /dollar, and redenominated in 2005 by cutting 6 zeros from the old lira, but not the cumulative transfer of wealth to the bankers through inflation. Following the transition period between 2005-2009, the new lira in 2009 was worth about 1.5 lira/dollar.

Note 9. Pamuk (2000, pp. 46,63,136,144,163,191,209), Central Bank of Turkey.

Note 10. TurkStat, 2000, pp. 102-142,142-148,170-171,172-173 price data (including 11 food and 5 non-food items) from 1469-1862 are derived from, (i) pious foundations (waqf) and their soup kitchens (imaret), (ii) the Topkapi palace kitchen (saray) and (iii) official price ceilings (narh) for basic items of consumption in the capital city of Istanbul. From 1863-1914, wholesale commodity price data (including 15 food and non-food items) are derived from the Commodity Exchange of Istanbul published by the Chamber of Commerce in Istanbul. Presented by Pamuk (1995, 2000, 2002, 2004a,b) in the form of a consumer price index.

Note 11. Wholesale commodity price data is derived from an index constructed by the Istanbul Chamber of Commerce from 1914-1941 (Pamuk, 1995, p. 97). Linear interpolated estimates were generated from observed values between 1914 and 1935. Official statistics published by the state statistical office (TurkStat) commenced from 1941.

Note 12. The Central Bank of the Republic of Turkey's (CBRT) wholesale commodity price data is derived from the Office of the Prime Minister, Under-Secretariat for the Treasury and Foreign Trade from 1938-1963, from the Istanbul Chamber of Commerce from 1963-2009; also available from the Turkish Statistical Institute, which adopts the Laspères weighted arithmetic average of price relatives formula.

Note 13. The akche was $1 / 4^{\text {th }}$ of the Tabriz mithqal or 6 karats $=6 \times 0.192=1.152 \mathrm{~g}$ and from 100 Tabriz mithqals 400 akche were minted (100 x 4.608 / 1.152).

Note 14. Per 100 dirham of 3.072g, 266 were minted in $1326(0.15 \mathrm{~g}), 290$ in $1444(1.06 \mathrm{~g}), 410$ in $1481(0.75 \mathrm{~g})$ and 450 in 1582 (0.68g) (Pamuk, 2000, pp. 46, 63).

Note 15. One of the main foreign creditors were the sabbatean Rothschilds, whom also effectively controlled the Ottoman Bank. Perhaps this explains why Kamal Atatuk at the heart of the Young Turk movement, who was apparently a doenmeh (apostate) being outwardly Muslim but inwardly a sabbatean Jew (Scholem, 1978, p. 331), abolished the Caliphate in 1924, turned the Topkapi mosque into a museum in 1924; opened the first Turkish public bank in 1924; changed the dress code in 1925; closed all Islamic courts, replacing Shariah Law in preference to common law in 1926 such that the Ottoman civil code, the Majallah, was replaced that year with a new civil code based on the Swiss and other European civil codes; and set up a central bank in 1931, which replaced the old Ottoman Bank (established in 1856 as a joint-venture partnership between 'British interests', the Banque de Paris and the Ottoman government).

\section{Copyrights}

Copyright for this article is retained by the author(s), with first publication rights granted to the journal.

This is an open-access article distributed under the terms and conditions of the Creative Commons Attribution license (http://creativecommons.org/licenses/by/3.0/). 